\title{
Glycogen Synthase Kinase $3 \beta$ in Cancer Biology and Treatment
}

\author{
Takahiro Domoto, Masahiro Uehara, Dilireba Bolidong and Toshinari Minamoto * \\ Division of Translational and Clinical Oncology, Cancer Research Institute, Kanazawa University, \\ Kanazawa 920-0934, Japan; tdomoto@staff.kanazawa-u.ac.jp (T.D.); masahiro.uehara@gmail.com (M.U.); \\ dilireba929@stu.kanazawa-u.ac.jp (D.B.) \\ * Correspondence: minamoto@staff.kanazawa-u.ac.jp; Tel.: +81-76-265-2798
}

Received: 15 April 2020; Accepted: 1 June 2020; Published: 3 June 2020

\begin{abstract}
Glycogen synthase kinase (GSK) $3 \beta$ is a multifunctional serine/threonine protein kinase with more than 100 substrates and interacting molecules. GSK3 $\beta$ is normally active in cells and negative regulation of GSK3 $\beta$ activity via phosphorylation of its serine 9 residue is required for most normal cells to maintain homeostasis. Aberrant expression and activity of GSK3 $\beta$ contributes to the pathogenesis and progression of common recalcitrant diseases such as glucose intolerance, neurodegenerative disorders and cancer. Despite recognized roles against several proto-oncoproteins and mediators of the epithelial-mesenchymal transition, deregulated GSK3 $\beta$ also participates in tumor cell survival, evasion of apoptosis, proliferation and invasion, as well as sustaining cancer stemness and inducing therapy resistance. A therapeutic effect from GSK3 $\beta$ inhibition has been demonstrated in 25 different cancer types. Moreover, there is increasing evidence that GSK3 $\beta$ inhibition protects normal cells and tissues from the harmful effects associated with conventional cancer therapies. Here, we review the evidence supporting aberrant GSK3 $\beta$ as a hallmark property of cancer and highlight the beneficial effects of GSK3 $\beta$ inhibition on normal cells and tissues during cancer therapy. The biological rationale for targeting GSK3 $\beta$ in the treatment of cancer is also discussed at length.
\end{abstract}

Keywords: glycogen synthase kinase $3 \beta$; cancer; biology; treatment

\section{GSK3 $\beta$ Biology in Normal Cells and Disease}

Glycogen synthase kinase (GSK) $3 \beta$ is an isoform of the GSK3 family of kinases. It regulates many fundamental biological processes in cells by phosphorylating serine and threonine residues and thus interacting with more than 100 functional and structural proteins [1-4]. The enzymatic activity of GSK3 $\beta$ is finely tuned through differential phosphorylation of its serine (S)9 (inactive form) and tyrosine (Y)216 (active form) residues. GSK3 $\beta$ is normally active in cells, but negative regulation of its activity via S9 phosphorylation allows normal cells to maintain vital activities and homeostasis upon intra- and extracellular stimuli [3,4]. Deregulated expression and activity of GSK3 $\beta$ and/or impairment of its negative regulation contributes to the pathogenesis and progression of common diseases including type 2 diabetes mellitus, neurodegenerative disorders associated with cognitive deficit, chronic inflammatory and immunological diseases and cancer [5-8]. These functions in normal cells and in primary pathologies have highlighted GSK3 $\beta$ as a potential drug target in a broad spectrum of diseases, thereby expediting the rapid development of pharmacological GSK3 $\beta$ inhibitors [9-11].

The biochemistry, function and regulation of GSK3 family kinases (GSK3 $\alpha$, GSK3 $\beta$ ) in normal cells and in disease have generated significant attention from chemistry, biomedical and pharmacology researchers. These have been extensively covered previously [3-11] and hence will not be the focus of this review. Instead, this review will focus on the critical roles that GSK3 $\beta$ has in cancer biology and treatment. 


\section{Overview of GSK3 $\beta$ Biology in Cancer}

GSK3 $\beta$ is a crucial member of the Wnt $/ \beta$-catenin-, hedgehog $(\mathrm{Hh})-$, notch- and c-myc-mediated major pro-oncogenic pathways, while also being a negative regulator of epithelial-mesenchymal transition (EMT) (reviewed in [12]). GSK3 $\beta$ has long been recognized to suppress tumor development and progression [12-14]. Several previous studies showed that GSK3 $\beta$ was inactivated mostly by S9 phosphorylation in various oncogenic pathways (reviewed in [15]). However, active GSK3 $\beta$ does not suppress the development and progression of tumors by disrupting the above-mentioned pro-oncogenic pathways and EMT, nor does the inhibition of GSK3 $\beta$ directly enhance tumorigenicity. Lithium is an ATP non-competitive and non-specific GSK3 inhibitor prescribed for bipolar disorder [16]. Long-term lithium treatment is associated with reduced kidney function and thyroid and parathyroid activity [17]. However, lithium treatment did not increase the incidence or mortality of cancer in large cohorts of patients with bipolar disorder compared to matched controls without lithium treatment [18,19]. Notably, in one of the latter control cohorts an increased risk of respiratory, gastrointestinal and endocrine cancers was observed compared to lithium-treated patients [18]. A recent systems biology study performed pathway and network enrichment analysis to explore the role of lithium in multiple cancer types and cancer-associated pathways, indicating the possible negative influence of lithium on the incidence of cancer and its therapeutic effects against cancer [20], as also discussed in the next section. These clinical observations on lithium treatment suggest that ATP-non-competitive inhibition of GSK $3 \beta$ is unlikely to cause tumor development and progression.

In contrast to the notion of GSK3 $\beta$ as a tumor suppressor, a growing number of studies over the past 15 years by our group and many others have instead shown that aberrant expression and activity of GSK3 $\beta$ facilitates the progression of various cancer types (reviewed in [21-23]). Pro-oncogenic activity for GSK3 $\beta$ is supported by the observation that deregulated GSK3 $\beta$ sustains tumor cell survival, proliferation and invasion by abrogating distinct tumor suppressor pathways and by enhancing cell immortality as well as the machinery for cell motility and migration. GSK3 $\beta$ also renders cancer cells resistant to chemotherapy, ionizing radiation and some molecular targeted agents [15]. In summary, accumulating evidence defines GSK3 $\beta$ as a potential therapeutic target in cancer [15,21-23], thus encouraging the development of GSK3 $\beta$ inhibitors for cancer treatment [24,25].

\section{Tumor-Promoting Roles of GSK3 $\beta$ in Various Cancer Types}

To date, the tumor-promoting functions of deregulated GSK3 $\beta$ have been reported in 25 cancer types from various organs and tissues across the body (Table 1) [26-160]. The majority of these studies have also demonstrated therapeutic effects against the respective cancer types using various pharmacological GSK3 $\beta$ inhibitors including lithium, natural products and medicines with GSK3 $\beta$-inhibiting activity, and GSK3 $\beta$-specific short interfering (si) or short hairpin (sh)RNA that are highly selective for GSK3 $\beta$ inhibition. The most extensively investigated cancer types to date are colon and rectum [161], pancreas [162-165] and prostate [166], as well as glioblastoma [167-169] and leukemia [170-172]. Compared to GSK3 $\beta$, only a few studies have investigated the tumor-promoting role of GSK3 $\alpha$, another isoform of the GSK3 family, in pancreatic cancer and acute myeloid leukemia [173-175].

Despite the concerns about putative tumor suppressor functions for GSK3 $\beta$ as outlined in the previous section, early phase clinical trials for solid cancer and leukemia have tested synthetic pharmacological GSK3 $\beta$ inhibitors, lithium and approved medicines with the ability to inhibit GSK3 $\beta$ (Table 2). Although these studies are still ongoing [176], some preliminary results have been published $[119,177,178]$. 
Table 1. Tumor-promoting property of GSK3 $\beta$ reported in various cancer types.

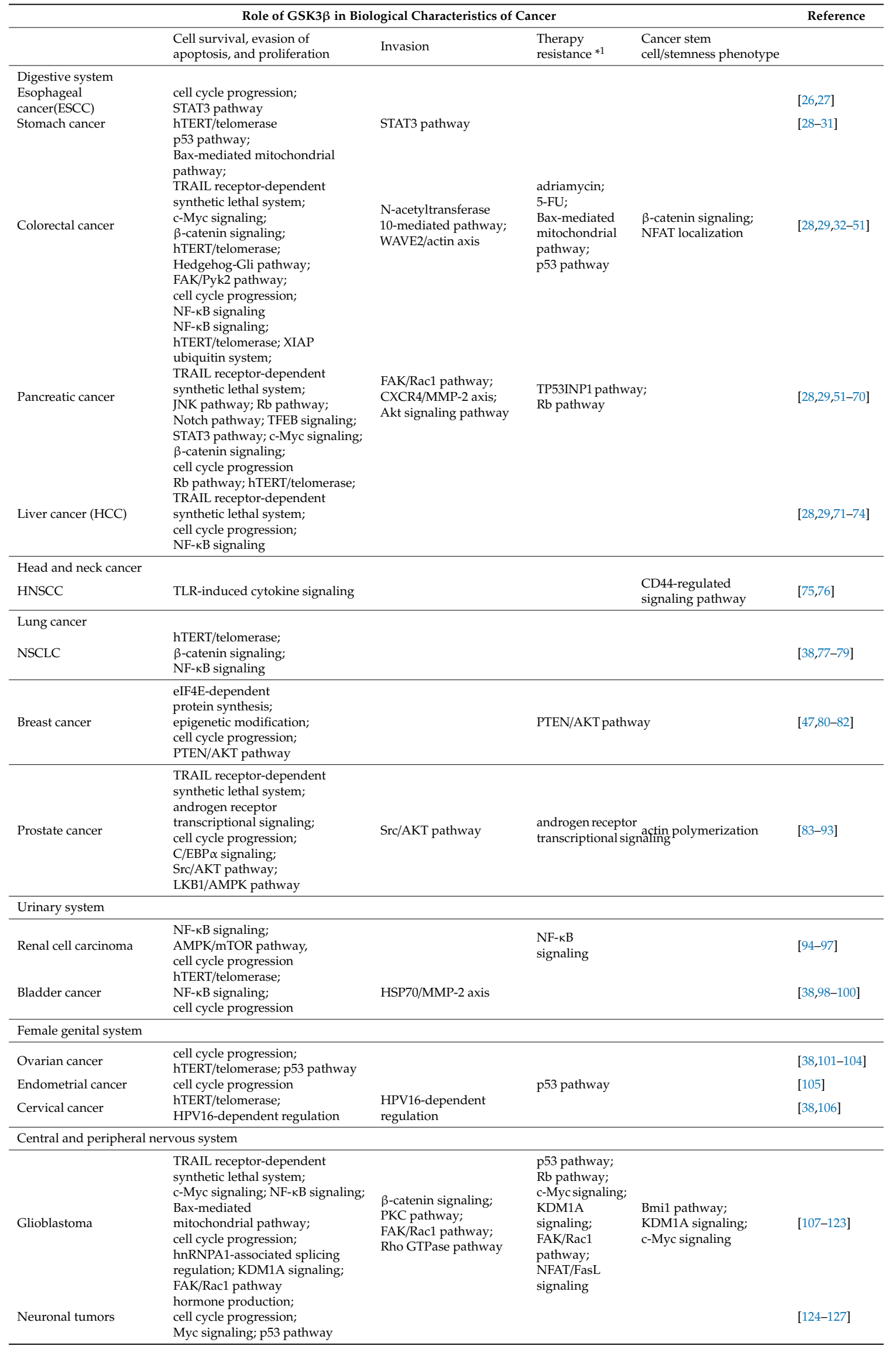


Table 1. Cont.

\begin{tabular}{|c|c|c|c|c|}
\hline \multicolumn{4}{|c|}{ Role of GSK3 $\beta$ in Biological Characteristics of Cancer } & \multirow[t]{2}{*}{ Reference } \\
\hline Hematopoietic system & & & & \\
\hline Myeloma & $\begin{array}{l}\text { NF-kB signaling; } \\
\beta \text {-catenin signaling; } \\
\text { cell cycle progression; } \\
\text { HOX-mediated transcription; } \\
\text { integrin-dependent } \\
\text { survival pathway; Bcl-2 pathway; } \\
\text { c-Myb signaling; } \\
\text { cell cycle progression; } \\
\text { mTOR/4EBP1 pathway; } \\
\text { MAPK cascade; VDR signaling; } \\
\text { T-BET signaling } \\
\text { FOXO signaling }\end{array}$ & $\begin{array}{l}\text { NF-kB signaling; } \\
\text { Akt/Foxo3A } \\
\text { pathway; } \\
\text { integrin-dependent } \\
\text { survival pathway; } \\
\text { RAR-mediated } \\
\text { differentiation }\end{array}$ & $\begin{array}{l}\text { HOX-mediated } \\
\text { transcription; } \\
\text { Bcl-2 pathway; } \\
\text { integrin-dependent } \\
\text { survival pathway }\end{array}$ & [128-144] \\
\hline \multicolumn{5}{|c|}{ Endocrine and neuroendocrine system } \\
\hline Thyroid cancer & $\begin{array}{l}\text { cell cycle progression; } \\
\text { hormone production }\end{array}$ & & & {$[146,147]$} \\
\hline Neuroendocrine tumors & $\begin{array}{l}\text { proteasome regulation; } \\
\text { cell cycle progression }\end{array}$ & \multicolumn{2}{|l|}{$\begin{array}{l}\text { cell cycle progression; } \\
\text { IRS-1/PI3K } \\
\text { pathway }\end{array}$} & [148-150] \\
\hline \multicolumn{5}{|l|}{ Bone and soft tissue } \\
\hline Osteosarcoma & $\begin{array}{l}\mathrm{NF}-\mathrm{kB} \text { signaling; } \beta \text {-catenin } \\
\text { signaling }\end{array}$ & \multirow{2}{*}{\multicolumn{2}{|c|}{ NF- $\kappa B$ signaling }} & [151-154] \\
\hline Soft tissue sarcomas & $\begin{array}{l}\text { PAX3-FKHR fusion } \\
\text { protein signaling; } \\
\beta \text {-catenin signaling; } \\
\text { cell cycle progression }\end{array}$ & & & [155-157] \\
\hline Melanoma & $\begin{array}{l}\text { p53 pathway; PAX3 signaling; } \\
\beta \text {-catenin signaling }\end{array}$ & \multicolumn{2}{|l|}{$\begin{array}{l}\beta \text {-catenin } \\
\text { signaling }\end{array}$} & [158-160] \\
\hline
\end{tabular}

Table 2. Clinical trials of GSK3 $\beta$ inhibitors for treatment of cancer *

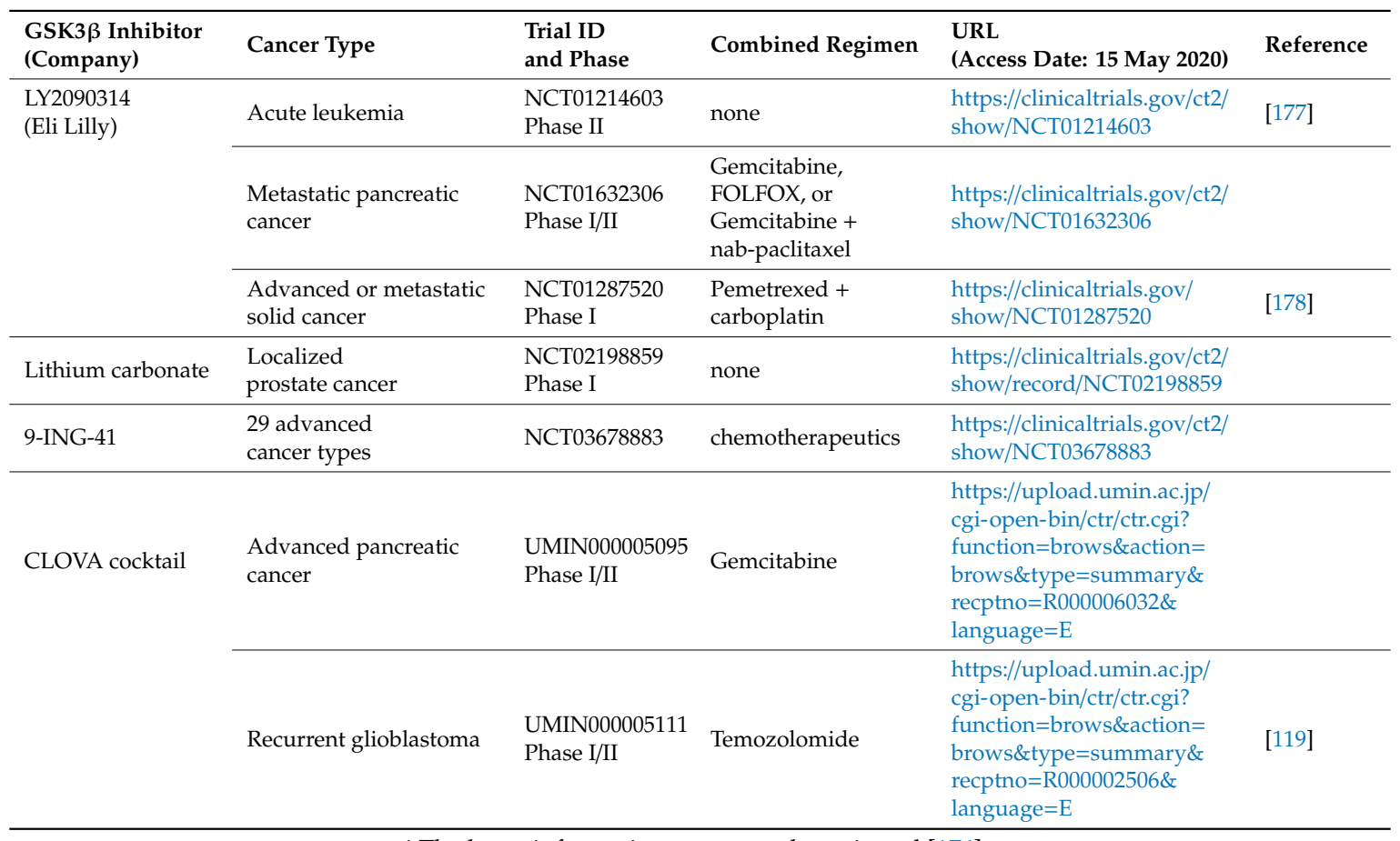

* The latest information was recently reviewed [176].

\section{Aberrant GSK3 $\beta$ and the Hallmark Properties of Cancer}

Thorough characterization of the underlying mechanistic basis for a novel therapy in the investigational phase is critical before it can proceed to clinical evaluation. Here we describe the pathological roles of deregulated GSK3 $\beta$ within the major hallmark properties of cancer [179], including tumor cell survival and proliferation, invasion, resistance to therapy and the tumor "stemness" phenotype (Table 1, Figure 1). 


\subsection{GSK3 $\beta$ and Tumor Cell Survival, Evasion of Apoptosis and Proliferation}

The most pronounced and common hallmark property of cancer is persistent tumor cell survival with evasion of apoptosis and proliferation [179]. As shown in Table 1, GSK3 $\beta$ sustains tumor cell survival in many cancer types by exploiting various pro-survival pathways mediated by nuclear factor (NF)к-B [48,52-55,63,78,94,95,98,107,128,129,151,153], Hh/Gli [43], mammalian target of rapamycin (mTOR) [97,140] and signal transducers and activators of transcription (STAT)3 [27,68]. Additionally, GSK3 $\beta$ helps tolerate apoptotic stimuli induced by the tumor necrosis factor-related apoptosis inducing ligand (TRAIL) receptor-dependent synthetic lethal system $[36,57,61,71,74,83,107]$. GSK3 $\beta$ can also perturb the p53-mediated tumor suppressor pathway [34,35,40,103,127,158] and Rb-mediated cell cycle regulatory machinery $[29,62,109]$. Sustained activity of human telomerase reverse transcriptase (hTERT) and telomerase in response to aberrant GSK3 $\beta$ contributes to the immortalization of tumor cells from the colon and rectum, pancreas, liver, lung, urinary bladder, ovary and uterine cervix [29,38]. Cell proliferation pathways mediated by c-Myc, cyclin D1 and STAT3 can promote unrestrained GSK3ß-dependent tumor cell proliferation [51-53,68,97,101,102,107,109,113,122,126,157].

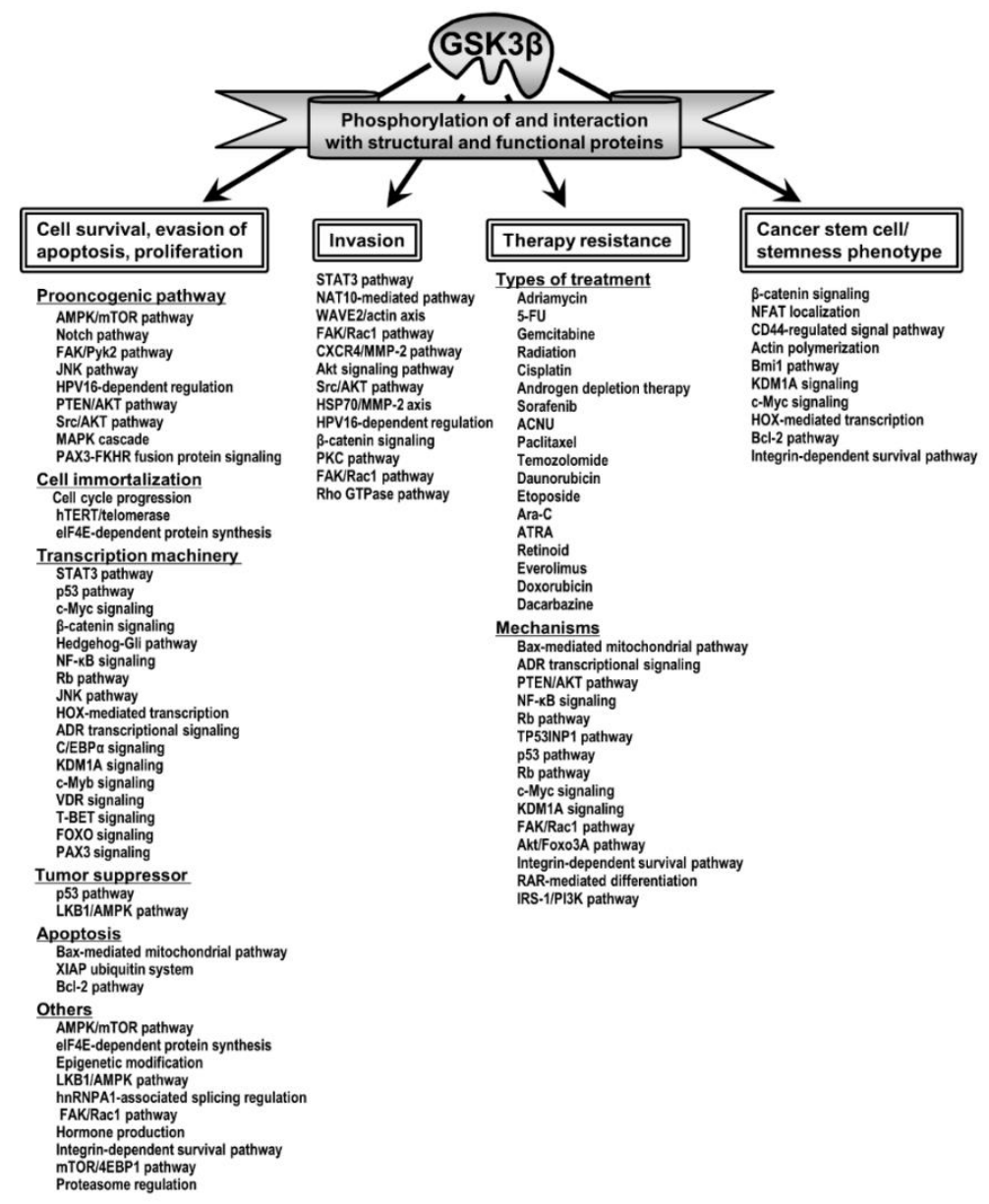

Figure 1. The tumor-promoting roles of GSK3 $\beta$ and the underlying mechanisms and pathways reported in the literature.

The dual functions of $\beta$-catenin consist of cell-to-cell adhesion and transcriptional co-activation of the T-cell factor (Tcf)/lymphoid enhancer factor (Lef) transcription factor. These functions depend on its subcellular localization in the cell membrane and nucleus and are responsible for tumor-suppressive and tumor-promoting roles, respectively, in several cancer types including colorectal cancer [180,181]. Paradoxically, the induction of Wnt/ $\beta$-catenin signaling through inhibition of GSK3 $\beta$ has been shown to suppress tumor cell survival and proliferation in osteosarcoma and rhabdomyosarcoma [152,157], 
pancreatic cancer and non-small cell lung cancer (NSCLC) $[51,70,77]$. This indirectly supports the notion that $\beta$-catenin acts as a tumor suppressor in these tumors (reviewed in [15]). It has been reported that inhibition of GSK3 $\beta$ in pancreatic cancer and NSCLC stabilizes $\beta$-catenin and thereby induces tumor cell death via transactivation of pro-apoptotic c-Myc [51]. Another study reported that upregulated $\beta$-catenin signaling does not affect the survival of pancreatic cancer cells during inhibition of GSK3 $\beta$ [70]. This suggests that a specific level of $\beta$-catenin signaling activity is required for tumor formation since excessive accumulation (activation) of $\beta$-catenin in normal and cancer cells leads to apoptosis [182,183]. It was also reported that $\beta$-catenin levels vary in different lung cancer cell lines undergoing knockdown of GSK3 $\beta$. This indicates that GSK3 $\beta$ may function independently of the $\beta$-catenin pathway in lung cancer, consistent with previous reports on colorectal, stomach, pancreatic and liver cancers [33,184-186]. In embryonal rhabdomyosarcoma, inhibition of GSK3 $\beta$ activates the canonical Wnt pathway by stabilizing $\beta$-catenin, leading to reduced tumor proliferation and differentiation of tumor stem-like cells and a reduction in their self-renewal capacity [156]. These results are consistent with a study showing the $\mathrm{Wnt} / \beta$-catenin pathway is essential for the transition from stem cell self-renewal to myogenic differentiation during muscle regeneration [187]. The putative tumor suppressor role of this pathway in osteosarcoma has yet to be investigated and is discussed further in Section 5.5.

Mitosis is a direct driving force for cancer cell propagation and has therefore long been recognized as a therapeutic target in cancer [188-190]. Previously, our group and others showed that GSK3 $\beta$ inhibition in colorectal, pancreatic and breast cancer cells induced mitotic catastrophe by disrupting biodynamic processes during the formation of mitotic microstructures (centrosomes, spindle apparatus and chromosomes), ultimately resulting in apoptosis $[47,50]$. This observation points to a critical role for GSK3 $\beta$ in the mitotic process.

Elevated glycolysis is one of the hallmark metabolic properties of cancer cells and provides strong selective pressure for malignant evolution in most cancer types [191-193]. Intermediate metabolites in the glycolysis pathway fuel the synthesis of biomacromolecules such as nucleic acids and structural proteins required for mitosis [191,192]. A recent preliminary study by our group (Bolidong D. et al., unpublished) revealed that GSK3 $\beta$ phosphorylates and inactivates glycogen synthase in esophageal squamous cell carcinoma (ESCC), which is characterized biochemically by the depletion of intracellular glycogen [194]. This observation suggests that deregulated GSK3 $\beta$ may shift ESCC cell metabolism from glycogenesis to the glycolytic pathway, thus fueling cell proliferation. Another previous study showed that GSK3 $\beta$ increased protein synthesis, thereby enhancing cell proliferation in breast cancer through regulation of the eukaryotic translation initiation factor 4E (eIF4E)-binding protein 1 (4E-BP1) [80]. In summary, GSK3 $\beta$ contributes to tumor cell survival and proliferation by interacting with distinct pro-oncogenic pathways, the cell cycle pathway, the mitotic process and probably also aberrant glycolysis.

\subsection{GSK3 $\beta$ and Tumor Invasion}

Tumor invasion of host tissues and organs generates the distinctive tumor microenvironment that is critical for metastasis, thus remaining a major challenge in the treatment of cancer $[195,196]$. The most noticeable cellular phenotype responsible for tumor invasion and metastasis is epithelial-mesenchymal transition (EMT). EMT is defined as the acquisition of mesenchymal phenotypes, both biological and morphological, by tumor cells of epithelial origin [197-199], although some controversies still exist [200]. An earlier study demonstrated that GSK3 $\beta$ inhibits transcription of snail, a repressor of E-cadherin, thus inducing EMT in normal breast epithelial cells [201]. This result suggests that GSK3 $\beta$ compromises the ability to invade by targeting the EMT mediator. However, no studies to date have shown that GSK3 $\beta$ inhibits EMT in tumor cells and attenuates their ability to invade. On the other hand, there is evidence that GSK3 $\beta$ participates in cytoskeletal organization, cell polarity, motility and migration during wound healing [202]. These same cellular events are also shared by tumor invasion. 
Previous studies reported that lithium and GSK3-inhibiting indirubins decreased the migration and invasion of glioblastoma cells $[108,112]$, suggesting a putative role for GSK3 $\beta$ in tumor invasion. Subsequently, we demonstrated that pharmacological GSK3 $\beta$-specific inhibitors reduced the migration and invasion of pancreatic cancer cells [62] and glioblastoma cells [116], both of which are highly invasive tumor types $[203,204]$. Inhibition of GSK3 $\beta$ was observed to suppress the formation of lamellipodia and invadopodia, which are the horizontal and vertical cell margin microstructures responsible for cell migration and stromal degradation $[205,206]$. These morphological changes in tumor cells induced by GSK3 $\beta$ inhibition coincided with the disruption of pathways that are mediated sequentially by focal adhesion kinase (FAK), guanine nucleotide exchange factors (GEFs), Rac1 and c-Jun $\mathrm{N}$-terminal kinase (JNK) (reviewed in [15]). Other studies have also demonstrated the pro-invasive nature of GSK3 $\beta$ in colorectal, pancreatic and breast cancer cells via the modulation of cytoskeletal microstructures and cytokine-mediated extracellular matrix degradation $[44,64,69]$. Together, these studies provide evidence that GSK3 $\beta$ enhances the process of tumor invasion and probably also that of metastatic spread.

\subsection{GSK3 $\beta$ and Therapy Resistance}

Resistance to therapy is an intractable biological characteristic of cancer and remains a major barrier to the success of current treatments with chemotherapeutics and radiation, as well as more recent molecular-targeted and immune-modulating agents [207]. Key biological events and determinants of resistance to cancer therapy include the ability of tumor cells to survive therapeutic insults, tumor heterogeneity, physical barriers to therapeutics due to intermingled stromal tissues, inflammatory and immune reactions in the tumor microenvironment, the presence of mutations in driver genes (e.g., K-ras) with no known inhibitors, and the consequences of therapeutic pressures [208]. In addition, a causal and pernicious interconnection between cancer invasion and therapy resistance has emerged which favors treatment failure [209]. In light of this, we previously reviewed the pivotal role of GSK3 $\beta$ as a hub that tightly connects the pathways and cellular events responsible for tumor invasion and resistance to therapy. We also documented how tumor types that acquire pro-invasive capacity as they evade therapeutic insults are also susceptible to experimental therapy that targets GSK3 $\beta$ [15].

A combination of multiple agents having different targets and mechanisms of action is frequently used to treat many diseases in order to optimize therapeutic efficacy, minimize adverse effects and prevent the development of therapy resistance. For the treatment of refractory cancers, molecular-targeted therapy is typically prescribed in combination with conventional chemotherapeutics and/or radiation therapy and with other targeted agents [210,211]. As shown in Table 1 and Figure 1 , several studies have reported that inhibition of GSK3 $\beta$ enhances the efficacy of chemotherapeutic agents and radiation in various cancer types. Conversely, this indicates that GSK3 $\beta$ renders tumor cells insensitive to cancer therapy. Importantly, these therapy resistant tumor types share the same pathways with their capacity of invasion, suggesting that GSK3 $\beta$ forms a pernicious cycle between tumor invasion and resistance to therapy in the refractory cancer types [15].

\subsection{GSK3 $\beta$, Cancer Stem Cells and the "Stemness" Phenotype}

Cancer initiating or stem-like cells (CSCs) are assumed to be at the origin of heterogeneous tumor cell populations in a broad spectrum of hematologic and solid malignancies [212]. Based on the theory of clonal evolution of tumorigenesis and on the normal stem cell (SC) concept [213], CSCs are defined conceptually as tumor cells with self-renewal capacity and pluripotent capabilities responsible for proliferation, invasion and metastasis, resistance to therapy and tumor relapse after surgery and adjuvant therapies [212,214]. Therefore, CSCs and related "stemness" phenotypes are potential targets in cancer treatment, albeit currently less feasible than other well-known targets [215]. Over the past several years, various compounds aimed at CSCs or "stemness" phenotypes have been developed, with some undergoing testing in clinical trials $[216,217]$. However, neither the identification nor the therapeutic targeting of CSCs has been as straightforward as initially hoped [212]. 
As discussed above, GSK3 $\beta$ participates in tumor cell survival, proliferation, invasion and therapy resistance. Considering the multiple roles played by CSCs in the biological hallmarks of cancer, a working hypothesis is that GSK3 $\beta$ is centrally involved in the underlying mechanism for sustaining CSC phenotypes. CSCs have been identified in glioblastoma and leukemia where they have undergone extensive studies [218,219]. As summarized in Table 1, an earlier study showed that GSK3 $\beta$ suppresses the differentiation of glioblastoma SCs in association with Bmi1, a polycomb group gene required for the self-renewal of neural stem cells [110]. Another study showed that GSK3 $\beta$ phosphorylates lysine-specific histone demethylase 1A (KDM1A), allowing stabilization by ubiquitin-specific peptidase (USP) 22 and thereby repressing the transcription of BMP2, CDKN1A and GATA6, and ultimately resulting in the self-renewal of glioma SCs [117]. Recently, our group screened compound libraries and identified kenpaullone, a pharmacological GSK3 $\beta$ inhibitor that attenuates the survival of patient-derived glioblastoma SCs via the c-Myc-mediated pathway [122]. In leukemia, GSK3 $\beta$ maintains the mixed-lineage leukemia (MLL) SC transcriptional program mediated by homeobox (HOX). This follows the conditional association of cyclic (c)AMP response element binding protein (CREB) and its co-activators TOR complex (TORC) and CREB-binding protein (CBP) with homeodomain protein MEIS1 (Meis homeobox 1), a critical component of the MLL-subordinate program [132]. It was also reported that GSK3 $\beta$ inhibitors suppress Bcl2-mediated and $\alpha 5 / \beta 1$-integrin-dependent cell survival pathways, thereby eliminating primitive leukemia progenitor/stem cells $[134,137,138]$. Other studies have implicated different mechanisms for the effects of GSK3 $\beta$ inhibition on CSCs from colorectal, head and neck and prostate cancer $[42,49,76,92]$.

In contrast to the role of GSK3 $\beta$ in CSCs, previous studies have indicated that GSK3 $\beta$ inhibition is essential for maintaining the "stemness" phenotype in embryonic and hematopoietic SCs. This is thought to be achieved through activation of the canonical Wnt/ $\beta$-catenin and Hh signaling cascades and by regulating cytoskeletal rearrangement [220-223], consistent with the physiological roles of GSK3 $\beta$ in normal cell biology $[3,4]$. Such reverse roles for GSK3 $\beta$ between normal and neoplastic SCs (reviewed in [170-172]) may ensure the safety of CSC-targeted therapy using GSK3 $\beta$ inhibition. Future studies on the role of GSK3 $\beta$ in normal and cancer SCs should; therefore, be aimed at elucidating the biological mechanisms that underlie selective eradication of CSCs.

In summary, the evidence described in this section places GSK3 $\beta$ at the center of a trigonal intersection between the biological hallmarks of cancer, notably tumor cell survival and proliferation, invasion, resistance to therapy and CSC phenotype (Figure 2).

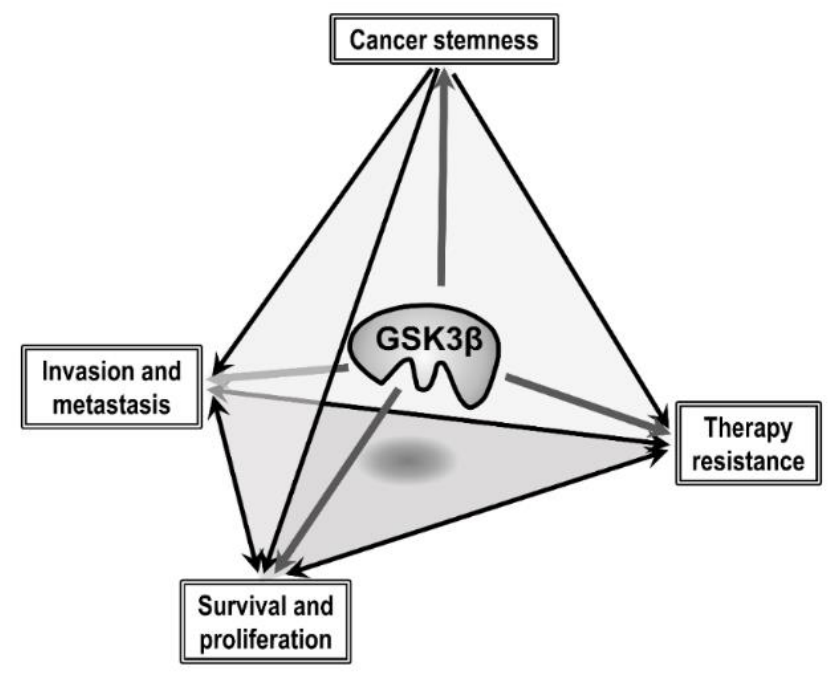

Figure 2. Schematic representation of the hypothesis that GSK3 $\beta$ is central to the interconnection between several of the biological hallmarks of cancer, including tumor cell survival and proliferation, invasion and metastasis, cancer stemness and resistance to therapy. 


\section{Protection of Normal Cells during Cancer Therapy by Targeting GSK3 $\beta$}

Targeting GSK3 $\beta$ for the treatment of diseases has raised concerns regarding the development and progression of cancer due to the promotion of proto-oncogenic pathways mediated by $W n t / \beta$-catenin and Hh signaling $[6,13,14]$. Another concern is the overall safety of systemic GSK3 $\beta$ inhibition, as this could have undesirable consequences following the disruption of multiple signaling pathways. However, as previously reviewed by our group $[15,21]$, it has yet to be demonstrated that GSK3 $\beta$ inhibition triggers neoplastic transformation or promotes any oncogenic process in normal cells. None of the studies on the tumor-promoting roles of GSK3 $\beta$ (Table 1) [26-160] showed any harmful effects of its inhibition on normal cells or vital organs in rodents. This is probably because GSK3 $\beta$ activity is finely controlled by a balanced, differential phosphorylation of its S9 and Y216 residues $[3,4]$, unlike many cancer types where the activity is deregulated by an excess of Y216 over S9 phosphorylation. Such observations should dispel any concerns about the safety of GSK3 $\beta$ inhibition. They also highlight a major advantage of targeting GSK3 $\beta$ for cancer therapy in that it can spare normal cells and tissues from the toxic side effects seen with conventional cancer therapy.

\subsection{GSK3 $\beta$ and Cancer Immunotherapy}

Recent advances in immunotherapy hold considerable promise for more effective treatment of cancer [224]. Among the innate immune reactions against cancer, natural killer (NK) cells are capable of directly destroying cancer cells without being restricted by the major histocompatibility complex (MHC). This is due to their expression of a diverse array of germline-encoded activating and inhibitory receptors $[225,226]$. Clinical trials have tested different NK cell-based therapies for cancer, particularly for hematological malignancies, but their efficacy was not as high as anticipated [227]. Therefore, increasing the activity of NK cells against cancer is a promising avenue for the clinical application of immunotherapy [228]. Recently, two groups showed that GSK3 $\beta$ inhibition in normal peripheral NK cells enhances their cytotoxic effects against acute myeloid leukemia (AML) cells $[143,144]$. These effects were associated with increased AML-NK cell conjugates via upregulation of lymphocyte function-associated antigen (LFA) expression on NK cells and by inducing the expression of intercellular adhesion molecule-1 (ICAM-1) on AML cells [143]. Inhibition of GSK3 $\beta$ was shown to facilitate the maturation of peripheral NK cells via increased surface expression of CD57, thereby enhancing their cytotoxic activity [144]. Therefore, GSK3 $\beta$ inhibition in AML has the dual effects of directly suppressing tumor cell survival and proliferation, and of activating innate NK cells to destroy the tumor cells.

The function of $\mathrm{CD} 8^{+}$memory T-cells is adoptive anti-tumor immunity. Following GSK3 $\beta$ inhibition these cells dedifferentiate into pluripotent memory stem T-cells with anti-tumor capacity via activation of the Wnt $/ \beta$-catenin pathway [229]. Consistent with this, a recent study showed that GSK3 $\beta$ inhibition increased the cytotoxic effect of $\mathrm{CD} 8^{+}$memory stem T-cells in gastric cancer through induction of effector T-cell-derived Fas-ligand [31]. Genetically engineered chimeric antigen receptor (CAR)-T cells have emerged as a new type of cancer immunotherapy and were recently approved for the treatment of leukemia and malignant lymphoma [230]. Similar to the effect on $\mathrm{CD} 8^{+}$memory T-cells, inhibition of GSK3 $\beta$ in mouse glioblastoma-specific CAR-T cells increased their survival, proliferation and memory phenotype generation, as well as enhancing their cytotoxic capacity [121]. These early results hold considerable promise for the targeting of GSK3 $\beta$ in T-cell-mediated anti-cancer immunotherapies.

Hematopoietic stem cell transplantation (HSCT) has long been the mainstay of curative therapy for hematological malignancies and most frequently for leukemia. However, its efficacy is diminished by graft versus host disease (GvHD). This immune complication occurs after both allogenic and autologous HSCT and is associated with considerable morbidity and mortality [231,232]. Immunosuppressive agents are used to prevent GvHD, but they increase the risk of disease relapse by inhibiting the graft versus leukemia effect. Thus, new treatments that prevent the relapse of leukemia are urgently required to address this serious concern. A previous study demonstrated that 3,6-bromoindirubin 3'-oxime (BIO), a GSK3 $\beta$ inhibitor, prevents lethal GvHD in a humanized xenograft in mice without affecting donor T-cell engraftment [233]. It also showed that BIO suppresses donor T-cell activity while reducing 
damage to bone marrow and liver by active donor T-cells. Subsequent studies showed that treatment with BIO preserves naïve T-cell phenotype by activating $\mathrm{Wnt} / \beta$-catenin and c-myc signaling pathways in mice with reconstituted bone marrow, thereby promoting early engraftment of ex vivo-expanded hematopoietic stem cells $[234,235]$. These experimental studies suggest a potential role for GSK3 $\beta$ inhibition in the prevention of GvHD.

\subsection{GSK3 $\beta$ and Cancer Therapy-Induced Hematotoxicity}

Hematotoxicity is defined as the unfavorable effects of toxic substances or stimuli on the hematopoietic system including erythrocytes, leukocytes and platelets [236]. Various cancer therapy regimens with chemotherapeutic agents and radiation are frequently associated with hematotoxicity due to their induction of heavy oxidative stress in healthy cells $[237,238]$. Therapy-induced hematotoxicity mainly involves leukocytopenia, thrombocytopenia and to a lesser extent erythrocythemia (anemia). It is often a limiting factor in cancer therapy and is occasionally lethal [237]. Interventions using pharmacological agents with antioxidant properties have failed to prevent hematotoxicity [239]. As discussed in Section 4.4, previous studies showed that inhibition of GSK3 $\beta$ is a prerequisite for "stemness" in hematopoietic SCs [220-223]. An earlier study also showed that upon S9 phosphorylation mediated by phosphoinositide 3 kinase (PI3K) signaling, GSK3 $\beta$ becomes inactive in platelets that have been stimulated with hemo-coagulant factors such as collagen and thrombin [240]. Moreover, GSK3 $\beta$ inhibitors suppress the aggregation of platelets, suggesting that GSK3 $\beta$ negatively regulates platelet functions. It is, therefore, conceivable that GSK3 $\beta$ inhibitors could mitigate the hematotoxicity associated with chemotherapy and radiation.

\subsection{GSK3 $\beta$ and Therapy-Induced Central and Peripheral Neuropathy}

Chemotherapy-induced peripheral neuropathy (CIPN) is one of the most frequently encountered adverse events in cancer patients, particularly those treated with taxanes and platinum derivatives. Sensory symptoms for CIPN include pain, sensory loss, paresthesia and numbness, typically in the hands and feet. These symptoms often limit the dose of chemotherapeutic agents that can be used and persist after the completion of scheduled chemotherapy [241]. Based on the putative biological and molecular mechanisms underlying CIPN [242], randomized clinical trials have tested various pharmacological agents for the treatment of this disorder. Only a phase-III trial with duloxetine has so far shown any significant efficacy. Following the results of these clinical trials, the National Cancer Institute's Symptom Management and Life Steering Committee has recognized CIPN as a priority area for translational research in cancer care (reviewed in [243,244]).

Since the pioneering study demonstrating that inhibition of GSK $3 \beta$ protects primary neurons of both the central and peripheral nervous systems [245], mounting evidence has confirmed the neuro-protective role of GSK3 $\beta$ inhibition [5-7]. Clinical trials have evaluated seed compounds for GSK3 $\beta$ inhibitors (e.g., tideglusib) in the treatment of Alzheimer's disease and bipolar disorder (reviewed in [15]). A recent study showed that dual inhibition of GSK3 $\beta$ and CDK5 protects the cytoskeleton of neurons from neuroinflammatory-mediated degeneration, a common biological characteristic of neurodegenerative disorders [246]. Co-administration of pharmacological GSK3 $\beta$ inhibitors prevents apoptosis of neural precursor cells and peripheral neuropathy induced by camptothecin and paclitaxel without impairing their chemotherapeutic efficacy [247,248].

Cranial irradiation is essential for the treatment of patients with brain tumors including glioblastoma. However, long-term or persistent cognitive deficit with impaired learning and memory often occurs as a consequence of radiation-induced hippocampal damage $[249,250]$. Consistent with the neuroprotective effect of GSK3 $\beta$ inhibition described above, experimental studies showed that pretreatment with GSK3 $\beta$ inhibitors prevents radiation-induced neuronal apoptosis in the subgranular zone of the hippocampus in irradiated mice, consequently improving their cognitive functions. This effect is associated with the reversal of radiation-induced p53 stabilization and repair of DNA double-strand breaks [251,252]. In addition to intracranial radiation, prophylactic chemotherapy 
directed at the central nervous system (CNS) increases the survival of children with leukemia. However, late neurocognitive sequelae remain a serious concern with this treatment [253]. A recent study investigating adult survivors following CNS-directed chemotherapy with methotrexate for childhood leukemia identified phosphorylated tau (p-tau) in cerebrospinal fluid as a predictor of late neurocognitive sequelae [254]. This study suggests a possible involvement of GSK3 $\beta$ in the pathogenesis of neurocognitive sequelae, since tau is a well-known substrate of GSK3 $\beta$ for phosphorylation and stabilization [3-5]. Moreover, $p$-tau together with $\beta$-amyloid are recognized pathogenic substances in neurodegenerative diseases [6-8]. Consequently, inhibition of GSK3 $\beta$ is a promising strategy for the prevention and treatment of harmful side effects in the central and peripheral nervous system associated with cancer therapy.

\subsection{GSK3 $\beta$ and Opioid-Induced Analgesic Tolerance and Withdrawal Syndrome}

Management of common distress symptoms (e.g., pain, breathlessness, nausea and vomiting, fatigue) in advanced cancer patients is a vital part of palliative care. By improving the quality of life and preserving treatment compliance, the effective management of symptoms can also improve patient survival [255]. Opioids such as morphine are widely used to relieve pain in patients with advanced cancer and in those with intolerable pain due to diseases such as chronic pancreatitis. However, long-term treatment with opioids causes gradual progression of analgesic tolerance and the risk of withdrawal symptoms, thus limiting their use for adequate pain control in palliative care [256].

Previous investigations of opioid-induced cellular events indicate that long term treatment with morphine suppresses activity of the PI3K/Akt pathway, resulting in activation of GSK3 $\beta$ via reduced S9 phosphorylation $[257,258]$. Consistent with this, subsequent studies showed that co-administration of lithium or pharmacological GSK3 $\beta$ inhibitors (BIO, SB216763, SB415286) with morphine attenuated chronic, morphine-induced tail-flick tolerance and alleviated withdrawal behaviors in rats under experimental pain stimuli [259-261]. Together, these studies suggest the involvement of GSK3 $\beta$ in undesirable, opioid-induced clinical events. GSK3 $\beta$ could, therefore, be a potential target that would allow adequate control of cancer pain by opioids.

\subsection{GSK3 $\beta$ and Normal Tissue Damage Associated with Surgery for Cancer}

Surgery remains the mainstay of treatment for patients with solid malignant tumors. However, the resultant defects in normal tissue adjacent to the tumor can be a serious issue, particularly for patients with musculoskeletal tumors such as bone and soft tissue sarcomas [262,263]. Adjuvant chemotherapy and radiation, either alone or in combination, are often used together with surgery to optimize tumor resection and minimize the defect in adjacent normal tissues [262,263]. In addition to these two adjuvant therapies, clinical trials have also begun to evaluate molecular-targeted agents for bone and soft tissue sarcomas, but have so far failed to show any significant efficacy [264,265]. Therefore, the identification of new therapeutic targets has been a high priority for the treatment of these tumors [266-268].

Recently, our group and others reported a therapeutic effect of GSK3 $\beta$ inhibition against osteosarcoma [151-154], rhabdomyosarcoma [155,156], synovial sarcoma and fibrosarcoma [157]. These malignancies comprise the majority of sarcomas encountered in orthopedics for surgical removal. The therapeutic effect was associated with activation of the $\beta$-catenin signaling pathway in osteosarcoma [152] and in rhabdomyosarcoma [156], consistent with the observation that Wnt/ $\beta$-catenin signaling is inactivated in these sarcomas $[269,270]$. A previous study also reported that undifferentiated sarcoma (or malignant fibrous histiocytoma, MFH) develops from mesenchymal stem cells (MSCs) via inactivation of the Wnt pathway [271], suggesting a pathogenic role for GSK3 $\beta$ in this tumor type. Accumulating evidence has shown the Wnt/ $\beta$-catenin pathway plays a key role in bone formation and homeostasis by inducing osteoblastogenesis and osteoblast differentiation, and by impairing osteoclastogenesis [272-276]. Osteoclasts in the tumor microenvironment have been shown to facilitate the progression of osteosarcoma [266]. Furthermore, inhibition of GSK3 $\beta$ protects skeletal muscle cells 
from apoptosis, promotes their differentiation $[277,278]$ and sustains the "stemness" and proliferation of MSCs $[279,280]$. Therefore, targeting of GSK3 $\beta$ in musculoskeletal tumors may have three advantages: direct therapeutic effect against the tumor, reduction of normal tissue defect caused by surgical removal of the tumor, and enhancement of adjacent normal tissue preservation.

Collectively, it can be deduced from the above review of the literature that GSK3 $\beta$-targeted cancer treatment would appear to confer much greater therapeutic advantages compared to the hypothetical risk of tumorigenesis.

\section{Future Perspectives on GSK3 $\beta$ in Cancer Treatment}

Current topics in oncology research and cancer therapies focus mainly on the regulation and targeting of immune checkpoints, the interleukin (IL)17-mediated Thelper (Th)17 cell immune reaction and mutant K-ras-driven oncogenic signaling in cancer. Here we discuss the potential involvement of GSK3 $\beta$ in these emerging therapeutic targets.

\subsection{GSK3 $\beta$ and the Regulation of Immune Checkpoints in Cancer}

Immunomodulation as a strategy for cancer treatment has attracted high levels of interest due to its potential for clinical translation. Therapeutic blockade of immune checkpoints involves the programmed death (PD)-1 and PD-ligand (PD-L)1 axis, as well as cytotoxic T-lymphocyte-associated protein (CTLA)-4 [281,282]. Briefly, the interaction between PD-L1 expressed on cancer cells and PD-1 produced by $\mathrm{CD} 8^{+} \mathrm{T}$-cells allows the cancer cells to evade the T-cell-based anti-cancer immune system. CTLA-4 belongs to the CD28 immunoglobulin superfamily and is expressed at the surface of both $\mathrm{CD}^{+} / \mathrm{CD} 8^{+} \mathrm{T}$-cells and $\mathrm{CD} 25^{+} /$forkhead box $\mathrm{P}$ (FOXP) $3^{+}$regulatory T-cells. CTLA- 4 competes with CD28 for binding to its ligands CD80 and CD86 on antigen-presenting cells, thus blocking T-cell immunity against cancer cells. Therapeutic antibodies against PD-1, PD-L1 and CTLA-4 have been evaluated in clinical trials of cancer treatment and several have been approved for the treatment of malignant melanoma and lung cancers. Gastrointestinal cancers also show response, in particular those with defective DNA mismatch-repair leading to microsatellite instability [282]. However, a large number of cancer patients undergoing treatment with these antibodies are unresponsive, highlighting the urgent need for accurate predictive biomarkers of treatment efficacy [283]. Treatment failure following immune checkpoint blockade is likely due to the evasion of cancer cells from the immune system, as well as innate and acquired therapy resistance [284,285]. While conventional chemotherapy and molecular-targeted therapy act mostly on cancer cells, immune checkpoint blockade can revitalize latent T-cell immunity resulting in "immune-related adverse events". These events frequently involve the gastrointestinal tract, liver, endocrine glands and skin, and less frequently the CNS, respiratory, cardiovascular, hematopoietic and musculoskeletal systems (reviewed in [286,287]).

As described in Section 5.1, inhibition of GSK3 $\beta$ causes CD8 ${ }^{+}$memory T-cells to dedifferentiate into progenitor $\mathrm{CD}^{+}$memory stem T-cells that are capable of self-renewal and cytotoxic effects [229]. Recent studies found that inactivation of GSK3 $\beta$ decreases PD-1 expression by up-regulating the transcription factor Tbx21 (Tbet), thereby enhancing CD8 ${ }^{+}$cytotoxic T-cell responses [288,289]. Another study showed that inhibition of poly [ADP-ribose] polymerase (PARP)1 increased the expression of PD-L1 in breast cancer cells directly via activation of GSK3 $\beta$ [290], suggesting that GSK3 $\beta$ is required for PARP1-regulated PD-L1 expression. In addition to the role of GSK3 $\beta$ in immune checkpoints mediated by the PD-1/PD-L1 axis, it was reported that inhibition of GSK3 $\beta$ reverses the blockade of CD28 by CTLA-4 [291] required to rescue exhausted CD8 ${ }^{+}$T-cells [292]. Collectively, these studies suggest involvement of GSK3 $\beta$ in the regulation of immune checkpoints by the PD-1/PD-L1 axis and by CTLA-4 in the cancer immunoenvironment [293]. Further studies may provide new insights into the potential role of GSK3 $\beta$ in the immune checkpoint mechanisms in cancer. In particular, research should investigate whether inhibition of GSK3 $\beta$ can increase the efficacy of immune checkpoint blockade, combat therapy resistance and improve immune-related adverse events. 


\subsection{GSK3 $\beta$ and the Regulation of IL-17/Th17 Immunity}

Interleukin (IL)-17 is a pleiotropic proinflammatory cytokine produced by CD4 ${ }^{+}$Th17-cells and by a variety of immune cells such as $\delta \gamma$ T-cells. IL-17 signaling-mediated inflammation promotes cancer-elicited inflammation and angiogenesis, as well as protecting cancer cells from immune surveillance (reviewed in [294,295]). Pro-tumorigenic effects of the IL-17-mediated pathway have been reported in colorectal and pancreatic cancers, where tumor infiltration by Th17-cells has been correlated with tumor progression and worse patient outcomes [296-298]. These results suggest that agents (e.g., antibodies) which target IL-17 or its receptor, or which impair the generation of Th17-cells, may represent a new therapeutic option in these cancer types.

Th17 cells are generated through a STAT3-dependent mechanism and IL-17 is thought to promote tumorigenesis and the progression of colorectal and pancreatic cancers via activation of IL-6/STAT3 and NF- $\mathrm{B}$ B signaling pathways [299-301]. As described in Sections 3 and 4, these cancer types have been extensively studied with regard to the tumor-promoting role of GSK3 $\beta$ (Table 1) [28,29,32-69]. It is also known that GSK3 $\beta$ enhances the STAT3-mediated pathway to facilitate tumor progression [30,302]. A previous study reported that GSK3 $\beta$ is a critical mediator of the differentiation of pathogenic Th17-cells via the IL6/STAT3 pathway in the mouse models of pulmonary bacterial infection and autoimmune encephalomyelitis (multiple sclerosis), respectively [303]. Taken together, these studies infer that GSK3 $\beta$ may positively regulate the tumor promoting function of IL-17/Th17 immunity, warranting further investigation.

\subsection{GSK3 $\beta$ and the Therapeutic Targeting of K-Ras Mutant Tumors}

Among the known cancer driver genes, gain-of-function mutation in the ras family of genes (K-, $\mathrm{N}$ - and $\mathrm{H}$-ras) is very prevalent. K-ras mutations are detected in almost one third of all human cancers and are especially common in pancreatic, colorectal and lung cancers [304]. K-ras oncoprotein is a constitutively active GTPase and provokes a diverse array of oncogenic signaling pathways mediated by Raf/MAPK kinase (MEK)/extracellular signal-regulated kinase (ERK), PI3K/Akt, RalGDS/Ral, T-lymphoma invasion and metastasis-1 (TIAM1)/Rac and p190/Rho axes. Activation of these pathways eventually facilitates tumor cell survival, proliferation, invasion, distinct metabolic reprogramming and therapy resistance [305]. Patients with K-ras-mutant colorectal cancer show unfavorable prognosis due to lack of response to epidermal growth factor receptor (EGFR)-targeted agents. Unfortunately, direct targeting of the K-ras oncoprotein has proven to be extremely difficult and is widely considered to be "undruggable" despite several attempts having been made for drugging this oncoprotein [306-310].

Recently, two direct covalent inhibitors of mutant K-ras ${ }^{\mathrm{G} 12 \mathrm{C}}$ oncoprotein, AMG 510 and MRTX849, were evaluated in phase I first-in-human clinical trials. Objective responses to these inhibitors were observed in about half of patients with lung cancer harboring K-ras ${ }^{\mathrm{G} 12 \mathrm{C}}$ mutation [311,312]. However, similar to receptor-type tyrosine kinase (RTK) inhibitors [313,314], acquired resistance to the mutant $\mathrm{K}-\mathrm{ras}{ }^{\mathrm{G} 12 \mathrm{C}}$ inhibitors was found to develop in an experimental setting via bypassing their effects against tumor proliferation by production of oncoprotein that did not bind to the inhibitors $[315,316]$. A subsequent experimental study showed that co-administration of Src homology region 2 domain-containing phosphatase-2 (SHP2) abrogates the adaptive response of cancer cells to the mutant $\mathrm{K}$-ras ${ }^{\mathrm{G} 12 \mathrm{C}}$ inhibitors. This resulted in suppression of the feedback reactivation of MAPK signaling, thereby inhibiting tumor proliferation [317,318]. Eventually however, this strategy leads to a spiral of drug development followed by the emergence of resistance, similar to the experience with RTK inhibitors [313,314].

A recent study has attempted to address the above dilemma of drug resistance. It showed that GSK3 $\beta$ is required for the survival and proliferation of human colorectal and pancreatic cancer cells that depend on mutant K-ras [51]. Stabilization of $\beta$-catenin and c-Myc proto-oncoproteins, which are substrates for phosphorylation by GSK3 $\beta$, was paradoxically associated with anti-tumor activity following GSK3 $\beta$ inhibition in these tumors. Inhibition of GSK3 $\beta$ also suppressed the growth of primary and metastatic patient-derived xenografts from pancreatic cancer patients who harbored K-ras 
mutations (G12D, G12V, G12C) and were resistant to chemo- and radiation therapies [51]. As described in Sections 3 and 4, the therapeutic efficacy of GSK3 $\beta$ inhibition is well established in colorectal, pancreatic and lung cancers regardless of their K-ras mutation status (Table 1) [28,29,32-69,77-79], even though these cancer types are characterized by very frequent K-ras mutations. Furthermore, recent studies have suggested the potential of immunotherapy and in particular of adoptive T-cell therapy for the efficient targeting of mutant K-ras [319,320]. As discussed in Sections 5.1 and 6.1, GSK3 $\beta$ is likely a negative regulator of adoptive T-cell-mediated immunity. Therefore, it would be interesting in future studies to elucidate whether adoptive T-cell-based and GSK3 $\beta$-targeted therapies can synergize to overcome the resistance of $\mathrm{K}$-ras mutant cancers to therapeutic agents.

\section{Conclusions}

This review has presented current knowledge regarding the tumor-promoting roles of GSK3 $\beta$ and the therapeutic efficacy of its inhibition. In addition, we describe potentially beneficial effects of GSK3 $\beta$ inhibition for the host and for normal cells following damage caused by conventional cancer therapy and palliative care. We also discussed the potential roles for GSK3 $\beta$ in sustaining the immune checkpoint machinery and IL-17/Th17 immunity, as well as in therapeutic targeting of K-ras mutant cancers. Taken together, this information provides a strong rationale for the targeting of GSK3 $\beta$ in the quest to cure cancer.

Author Contributions: Conceptualization, T.D. and T.M.; Literature Research, T.D., M.U., D.B. and T.M.; Original Draft Preparation, T.D. and T.M.; Writing, Review and Editing, T.D., M.U., D.B. and T.M.; All authors have read and agreed to published version of manuscript.

Funding: This study was supported by Grants-In-Aid for Scientific Research from the Ministry of Education, Science, Sports, Technology and Culture and from the Japan Society for the Promotion of Science (to T. Domoto and T. Minamoto).

Acknowledgments: We acknowledge Barry Iacopetta (University of Western Australia) for critical review and editing of the manuscript.

Conflicts of Interest: The authors have no conflicts of interest.

$\begin{array}{ll}\text { Abbreviations } \\ \text { 4EBP1 } & \text { eukaryotic translation initiation factor 4E-binding protein 1 } \\ \text { 5-FU } & \text { 5-fluorouracil } \\ \text { ACNU } & \text { nimustine hydrochloride } \\ \text { AMP } & \text { adenosine monophosphate } \\ \text { AMPK } & \text { AMP-activated protein kinase } \\ \text { Ara-C } & \text { cytosine arabinoside } \\ \text { ARHGAP } & \text { Rho GTPase-activating protein } \\ \text { ATRA } & \text { all-trans retinoic acid } \\ \text { Bax } & \text { Bcl-2-assosicated X protein } \\ \text { Bcl-2 } & \text { B-cell lymphoma 2 } \\ \text { Bmi1 } & \text { B cell-specific Moloney murine leukemia virus integration site 1 } \\ \text { CDK } & \text { cyclin-dependent kinase } \\ \text { C/EBP } \alpha & \text { CCAAT/enhancer binding protein } \alpha \\ \text { CLOVA } & \text { combined cimetidine, lithium chloride, olanzapine and valproate regimen } \\ \text { c-Myb } & \text { avian myeloblastosis virus oncogene cellular homolog } \\ \text { c-Myc } & \text { cellular myelocytomatosis } \\ \text { CXCR4 } & \text { C-X-C chemokine receptor type 4 } \\ \text { eIF4E } & \text { eukaryotic initiation factor-4E } \\ \text { ESCC } & \text { esophageal SCC } \\ \text { FAK } & \text { focal adhesion kinase } \\ \text { FasL } & \text { Fas ligand } \\ \text { FKHR } & \text { Forkhead in rhabdomyosarcoma } \\ \end{array}$




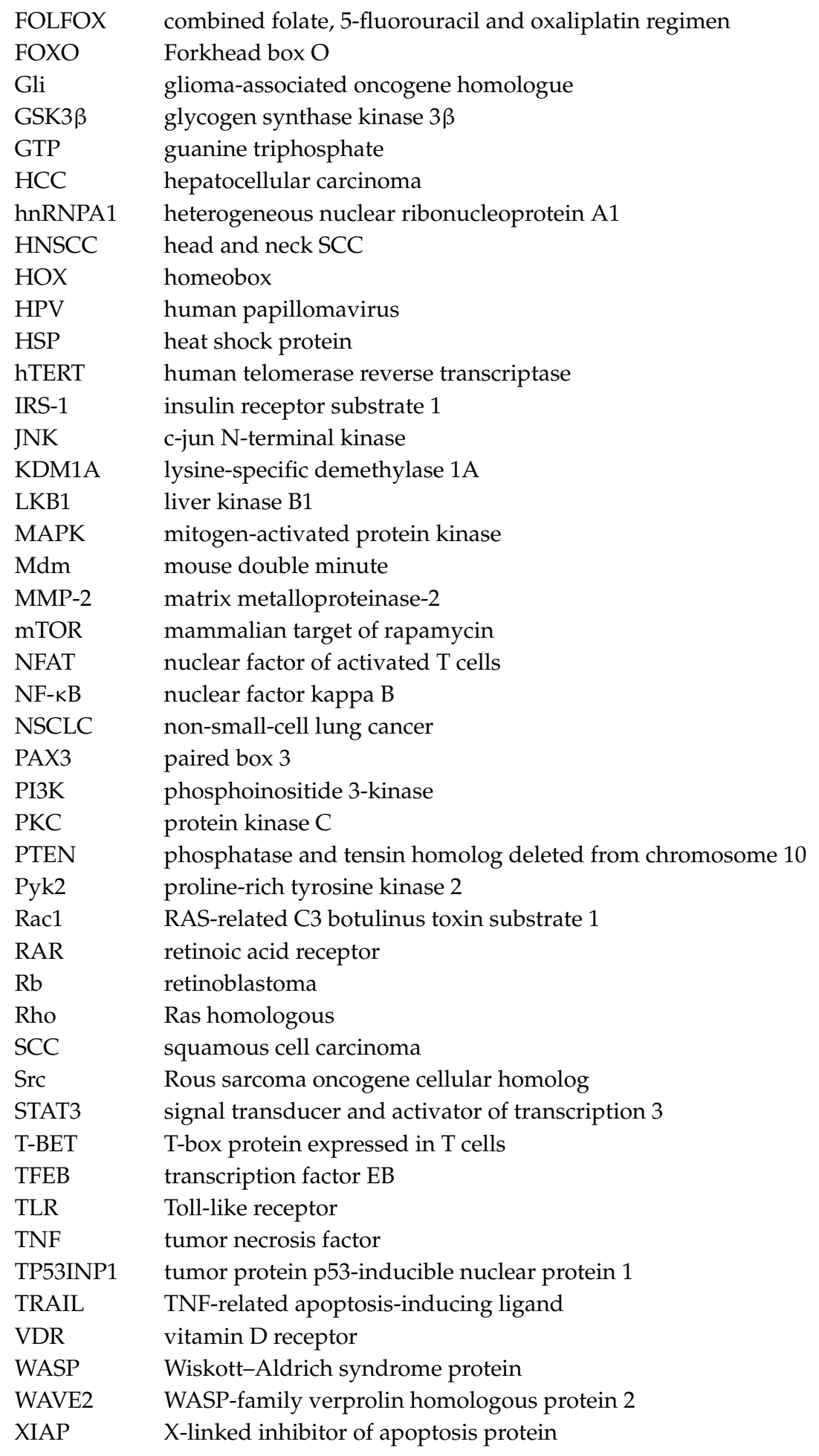

\section{References}

1. $\mathrm{Xu}, \mathrm{C} . ; \mathrm{Kim}$, N.G.; Gumbiner, B.M. Regulation of protein stability by GSK3 mediated phosphorylation. Cell Cycle 2009, 8, 4032-4039. [CrossRef] [PubMed]

2. Gao, X.; Wang, J.Y.; Gao, L.M.; Yin, X.F.; Liu, L. Identification and analysis of glycogen synthase kinase $3 \beta 1$ interactome. Cell Biol. Int. 2013, 37, 768-779. [CrossRef]

3. Cormier, K.W.; Woodgett, J.R. Recent advances in understanding the cellular roles of GSK-3. F1000Res 2017, 6. [CrossRef] [PubMed] 
4. Patel, P.; Woodgett, J.R. Glycogen synthase kinase 3: A kinase for all pathways? Curr. Top. Dev. Biol. 2017, 123, 277-302. [CrossRef] [PubMed]

5. Amar, S.; Belmaker, R.H.; Agam, G. The possible involvement of glycogen synthase kinase-3 (GSK-3) in diabetes, cancer and central nervous system diseases. Curr. Pharm. Des. 2011, 17, 2264-2277. [CrossRef] [PubMed]

6. Takahashi-Yanaga, F. Activator or inhibitor? GSK-3 as a new drug target. Biochem. Pharmacol. 2013, 86, 191-199. [CrossRef]

7. Beurel, E.; Grieco, S.F.; Jope, R.S. Glycogen synthase kinase-3 (GSK3): Regulation, actions, and diseases. Pharmacol. Ther. 2015, 148, 114-131. [CrossRef]

8. McCubrey, J.A.; Cocco, L. GSK-3 signaling in health. Adv. Biol. Regul. 2017, 65, 1-4. [CrossRef]

9. Khan, I.; Tantray, M.A.; Alam, M.S.; Hamid, H. Natural and synthetic bioactive inhibitors of glycogen synthase kinase. Eur. J. Med. Chem. 2017, 125, 464-477. [CrossRef]

10. Palomo, V.; Martinez, A. Glycogen synthase kinase 3 (GSK-3) inhibitors: A patent update (2014-2015). Expert Opin. Ther. Pat. 2017, 27, 657-666. [CrossRef]

11. Saraswati, A.P.; Ali Hussaini, S.M.; Krishna, N.H.; Babu, B.N.; Kamal, A. Glycogen synthase kinase-3 and its inhibitors: Potential target for various therapeutic conditions. Eur. J. Med. Chem. 2018, 144, 843-858. [CrossRef] [PubMed]

12. Nagini, S.; Sophia, J.; Mishra, R. Glycogen synthase kinases: Moonlighting proteins with theranostic potential in cancer. Semin. Cancer Biol. 2019, 56, 25-36. [CrossRef]

13. Luo, J. Glycogen synthase kinase $3 \beta$ (GSK3 $\beta$ ) in tumorigenesis and cancer chemotherapy. Cancer Lett. 2009, 273, 194-200. [CrossRef]

14. McCubrey, J.A.; Davis, N.M.; Abrams, S.L.; Montalto, G.; Cervello, M.; Basecke, J.; Libra, M.; Nicoletti, F.; Cocco, L.; Martelli, A.M.; et al. Diverse roles of GSK-3: Tumor promoter-tumor suppressor, target in cancer therapy. Adv. Biol. Regul. 2014, 54, 176-196. [CrossRef] [PubMed]

15. Domoto, T.; Pyko, I.V.; Furuta, T.; Miyashita, K.; Uehara, M.; Shimasaki, T.; Nakada, M.; Minamoto, T. Glycogen synthase kinase- $3 \beta$ is a pivotal mediator of cancer invasion and resistance to therapy. Cancer Sci. 2016, 107, 1363-1372. [CrossRef]

16. Malhi, G.S. Lithium therapy in bipolar disorder: A balancing act? The Lancet 2015, 386, 415-416. [CrossRef]

17. Shine, B.; McKnight, R.F.; Leaver, L.; Geddes, J.R. Long-term effects of lithium on renal, thyroid, and parathyroid function: A retrospective analysis of laboratory data. The Lancet 2015, 386, 461-468. [CrossRef]

18. Martinsson, L.; Westman, J.; Hällgren, J.; Ösby, U.; Backlund, L. Lithium treatment and cancer incidence in bipolar disorder. Bipolar Disord. 2016, 18, 33-40. [CrossRef]

19. Huang, R.Y.; Hsieh, K.P.; Huang, W.W.; Yang, Y.H. Use of lithium and cancer risk in patients with bipolar disorder: Population-based cohort study. Br. J. Psychiatry 2016, 209, 393-399. [CrossRef]

20. Ge, W.; Jakobsson, E. Systems biology understanding of the effects of lithium on cancer. Front. Oncol. 2019, 9, 296. [CrossRef]

21. Miyashita, K.; Nakada, M.; Shakoori, A.; Ishigaki, Y.; Shimasaki, T.; Motoo, Y.; Kawakami, K.; Minamoto, T. An emerging strategy for cancer treatment targeting aberrant glycogen synthase kinase $3 \beta$. Anticancer Agents Med. Chem. 2009, 9, 1114-1122. [CrossRef] [PubMed]

22. McCubrey, J.A.; Steelman, L.S.; Bertrand, F.E.; Davis, N.M.; Sokolosky, M.; Abrams, S.L.; Montalto, G.; D'Assoro, A.B.; Libra, M.; Nicoletti, F.; et al. GSK-3 as potential target for therapeutic intervention in cancer. Oncotarget 2014, 5, 2881-2911. [CrossRef] [PubMed]

23. Walz, A.; Ugolkov, A.; Chandra, S.; Kozikowski, A.; Carneiro, B.A.; O’Halloran, T.V.; Giles, F.J.; Billadeau, D.D.; Mazar, A.P. Molecular pathways: Revisiting glycogen synthase kinase-3 $\beta$ as a target for the treatment of cancer. Clin. Cancer Res. 2017, 23, 1891-1897. [CrossRef] [PubMed]

24. Osolodkin, D.I.; Palyulin, V.A.; Zefirov, N.S. Glycogen synthase kinase 3 as an anticancer drug target: Novel experimental findings and trends in the design of inhibitors. Curr. Pharm. Des. 2013, 19, 665-679. [CrossRef] [PubMed]

25. Sahin, I.; Eturi, A.; De Souza, A.; Pamarthy, S.; Tavora, F.; Giles, F.J.; Carneiro, B.A. Glycogen synthase kinase-3 $\beta$ inhibitors as novel cancer treatments and modulators of antitumor immune responses. Cancer Biol. Ther. 2019, 20, 1047-1056. [CrossRef] [PubMed] 
26. Wang, J.S.; Wang, C.L.; Wen, J.F.; Wang, Y.J.; Hu, Y.B.; Ren, H.Z. Lithium inhibits proliferation of human esophageal cancer cell line Eca-109 by inducing a G2/M cell cycle arrest. World J. Gastroenterol. 2008, 14, 3982-3989. [CrossRef]

27. Gao, S.; Li, S.; Duan, X.; Gu, Z.; Ma, Z.; Yuan, X.; Feng, X.; Wang, H. Inhibition of glycogen synthase kinase $3 \beta$ (GSK3 $\beta$ ) suppresses the progression of esophageal squamous cell carcinoma by modifying STAT3 activity. Mol. Carcinog. 2017, 56, 2301-2316. [CrossRef]

28. Mai, W.; Miyashita, K.; Shakoori, A.; Zhang, B.; Yu, Z.W.; Takahashi, Y.; Motoo, Y.; Kawakami, K.; Minamoto, T. Detection of active fraction of glycogen synthase kinase $3 \beta$ in cancer cells by nonradioisotopic in vitro kinase assay. Oncology 2006, 71, 297-305. [CrossRef]

29. Mai, W.; Kawakami, K.; Shakoori, A.; Kyo, S.; Miyashita, K.; Yokoi, K.; Jin, M.; Shimasaki, T.; Motoo, Y.; Minamoto, T. Deregulated GSK3 $\beta$ sustains gastrointestinal cancer cells survival by modulating human telomerase reverse transcriptase and telomerase. Clin. Cancer Res. 2009, 15, 6810-6819. [CrossRef]

30. Yoon, J.; Ko, Y.S.; Cho, S.J.; Park, J.; Choi, Y.S.; Choi, Y.; Pyo, J.S.; Ye, S.K.; Youn, H.D.; Lee, J.S.; et al. Signal transducers and activators of transcription 3-induced metastatic potential in gastric cancer cells is enhanced by glycogen synthase kinase-3ß. APMIS 2015, 123, 373-382. [CrossRef]

31. Zhang, J.Y.; Zhao, Y.L.; Lv, Y.P.; Cheng, P.; Chen, W.; Duan, M.; Teng, Y.S.; Wang, T.T.; Peng, L.S.; Mao, F.Y.; et al. Modulation of CD8(+) memory stem $\mathrm{T}$ cell activity and glycogen synthase kinase $3 \beta$ inhibition enhances anti-tumoral immunity in gastric cancer. Oncoimmunology 2018, 7, e1412900. [CrossRef]

32. Gould, T.D.; Gray, N.A.; Manji, H.K. Effects of a glycogen synthase kinase-3 inhibitor, lithium, in adenomatous polyposis coli mutant mice. Pharmacol. Res. 2003, 48, 49-53. [CrossRef]

33. Shakoori, A.; Ougolkov, A.; Yu, Z.W.; Zhang, B.; Modarressi, M.H.; Billadeau, D.D.; Mai, M.; Takahashi, Y.; Minamoto, T. Deregulated GSK3 $\beta$ activity in colorectal cancer: Its association with tumor cell survival and proliferation. Biochem. Biophys. Res. Commun. 2005, 334, 1365-1373. [CrossRef]

34. Ghosh, J.C.; Altieri, D.C. Activation of p53-dependent apoptosis by acute ablation of glycogen synthase kinase-3 $\beta$ in colorectal cancer cells. Clin. Cancer Res. 2005, 11, 4580-4588. [CrossRef] [PubMed]

35. Tan, J.; Zhuang, L.; Leong, H.S.; Iyer, N.G.; Liu, E.T.; Yu, Q. Pharmacologic modulation of glycogen synthase kinase- $3 \beta$ promotes p53-dependent apoptosis through a direct Bax-mediated mitochondrial pathway in colorectal cancer cells. Cancer Res. 2005, 65, 9012-9020. [CrossRef] [PubMed]

36. Rottmann, S.; Wang, Y.; Nasoff, M.; Deveraux, Q.L.; Quon, K.C. A TRAIL receptor-dependent synthetic lethal relationship between MYC activation and GSK3 $\beta /$ FBW7 loss of function. Proc. Natl. Acad. Sci. USA 2005, 102, 15195-15200. [CrossRef] [PubMed]

37. Shakoori, A.; Mai, W.; Miyashita, K.; Yasumoto, K.; Takahashi, Y.; Ooi, A.; Kawakami, K.; Minamoto, T. Inhibition of GSK-3 $\beta$ activity attenuates proliferation of human colon cancer cells in rodents. Cancer Sci. 2007, 98, 1388-1393. [CrossRef]

38. Bilsland, A.E.; Hoare, S.; Stevenson, K.; Plumb, J.; Gomez-Roman, N.; Cairney, C.; Burns, S.; Lafferty-Whyte, K.; Roffey, J.; Hammonds, T.; et al. Dynamic telomerase gene suppression via network effects of GSK3 inhibition. PLoS ONE 2009, 4, e6459. [CrossRef]

39. Mayes, P.A.; Dolloff, N.G.; Daniel, C.J.; Liu, J.J.; Hart, L.S.; Kuribayashi, K.; Allen, J.E.; Jee, D.I.; Dorsey, J.F.; Liu, Y.Y.; et al. Overcoming hypoxia-induced apoptotic resistance through combinatorial inhibition of GSK-3 $\beta$ and CDK1. Cancer Res. 2011, 71, 5265-5275. [CrossRef]

40. Deevi, R.; Fatehullah, A.; Jagan, I.; Nagaraju, M.; Bingham, V.; Campbell, F.C. PTEN regulates colorectal epithelial apoptosis through Cdc42 signalling. Br. J. Cancer 2011, 105, 1313-1321. [CrossRef]

41. Grassilli, E.; Narloch, R.; Federzoni, E.; Ianzano, L.; Pisano, F.; Giovannoni, R.; Romano, G.; Masiero, L.; Leone, B.E.; Bonin, S.; et al. Inhibition of GSK3B bypass drug resistance of p53-null colon carcinomas by enabling necroptosis in response to chemotherapy. Clin. Cancer Res. 2013, 19, 3820-3831. [CrossRef] [PubMed]

42. Turano, M.; Costabile, V.; Cerasuolo, A.; Duraturo, F.; Liccardo, R.; Delrio, P.; Pace, U.; Rega, D.; Dodaro, C.A.; Milone, M.; et al. Characterisation of mesenchymal colon tumour-derived cells in tumourspheres as a model for colorectal cancer progression. Int. J. Oncol. 2018, 53, 2379-2396. [CrossRef] [PubMed]

43. Trnski, D.; Sabol, M.; Gojević, A.; Martinić, M.; Ozretić, P.; Musani, V.; Ramić, S.; Levanat, S. GSK3 $\beta$ and Gli3 play a role in activation of Hedgehog-Gli pathway in human colon cancer-Targeting GSK3 $\beta$ downregulates the signaling pathway and reduces cell proliferation. Biochim. Biophys. Acta 2015, 1852, 2574-2584. [CrossRef] 
44. Yoshino, Y.; Suzuki, M.; Takahashi, H.; Ishioka, C. Inhibition of invasion by glycogen synthase kinase-3 $\beta$ inhibitors through dysregulation of actin re-organisation via down-regulation of WAVE2. Biochem. Biophys. Res. Commun. 2015, 464, 275-280. [CrossRef] [PubMed]

45. Costabile, V.; Duraturo, F.; Delrio, P.; Rega, D.; Pace, U.; Liccardo, R.; Rossi, G.B.; Genesio, R.; Nitsch, L.; Izzo, P.; et al. Lithium chloride induces mesenchymal-to-epithelial reverting transition in primary colon cancer cell cultures. Int. J. Oncol. 2015, 46, 1913-1923. [CrossRef]

46. Gao, C.; Chen, G.; Kuan, S.F.; Zhang, D.H.; Schlaepfer, D.D.; Hu, J. FAK/PYK2 promotes the Wnt/ $\beta$-catenin pathway and intestinal tumorigenesis by phosphorylating GSK3 $\beta$. Elife 2015, 4. [CrossRef]

47. Yoshino, Y.; Ishioka, C. Inhibition of glycogen synthase kinase- $3 \beta$ induces apoptosis and mitotic catastrophe by disrupting centrosome regulation in cancer cells. Sci. Rep. 2015, 5, 13249. [CrossRef]

48. Saud, S.M.; Li, W.; Gray, Z.; Matter, M.S.; Colburn, N.H.; Young, M.R.; Kim, Y.S. Diallyl disulfide (DADS), a constituent of garlic, inactivates NF- $\mathrm{KB}$ and prevents colitis-induced colorectal cancer by inhibiting GSK-3 $\beta$. Cancer Prev. Res. 2016, 9, 607-615. [CrossRef]

49. Ishida, R.; Koyanagi-Aoi, M.; Oshima, N.; Kakeji, Y.; Aoi, T. The tissue-reconstructing ability of colon CSCs is enhanced by FK506 and suppressed by GSK3 inhibition. Mol. Cancer Res. 2017, 15, 1455-1466. [CrossRef]

50. Dewi, F.R.P.; Domoto, T.; Hazawa, M.; Kobayashi, A.; Douwaki, T.; Minamoto, T.; Wong, R.W. Colorectal cancer cells require glycogen synthase kinase- $3 \beta$ for sustaining mitosis via translocated promoter region (TPR)-dynein interaction. Oncotarget 2018, 9, 13337-13352. [CrossRef]

51. Kazi, A.; Xiang, S.; Yang, H.; Delitto, D.; Trevino, J.; Jiang, R.H.Y.; Ayaz, M.; Lawrence, H.R.; Kennedy, P.; Sebti, S.M. GSK3 suppression upregulates $\beta$-catenin and c-Myc to abrogate KRas-dependent tumors. Nat. Commun. 2018, 9, 5154. [CrossRef] [PubMed]

52. Ougolkov, A.V.; Fernandez-Zapico, M.E.; Savoy, D.N.; Urrutia, R.A.; Billadeau, D.D. Glycogen synthase kinase-3 $\beta$ participates in nuclear factor $\mathrm{kB}$-mediated gene transcription and cell survival in pancreatic cancer cells. Cancer Res. 2005, 65, 2076-2081. [CrossRef] [PubMed]

53. Ougolkov, A.V.; Fernandez-Zapico, M.E.; Bilim, V.N.; Smyrk, T.C.; Chari, S.T.; Billadeau, D.D. Aberrant nuclear accumulation of glycogen synthase kinase- $3 \beta$ in human pancreatic cancer: Association with kinase activity and tumor dedifferentiation. Clin. Cancer Res. 2006, 12, 5074-5081. [CrossRef] [PubMed]

54. Wilson, W.; Baldwin, A.S. Maintenance of constitutive IкB kinase activity by glycogen synthase kinase- $3 \alpha / \beta$ in pancreatic cancer. Cancer Res. 2008, 68, 8156-8163. [CrossRef] [PubMed]

55. Mamaghani, S.; Patel, S.; Hedley, D.W. Glycogen synthase kinase-3 inhibition disrupts nuclear factor- $\mathrm{B}$ activity in pancreatic cancer, but fails to sensitize to gemcitabine chemotherapy. BMC Cancer 2009, 9, 132. [CrossRef] [PubMed]

56. Gaisina, I.N.; Gallier, F.; Ougolkov, A.V.; Kim, K.H.; Kurome, T.; Guo, S.; Holzle, D.; Luchini, D.N.; Blond, S.Y.; Billadeau, D.D.; et al. From a natural product lead to the identification of potent and selective benzofuran-3-yl-(indol-3-yl)maleimides as glycogen synthase kinase $3 \beta$ inhibitors that suppress proliferation and survival of pancreatic cancer cells. J. Med. Chem. 2009, 52, 1853-1863. [CrossRef]

57. Guzmán, E.A.; Johnson, J.D.; Linley, P.A.; Gunasekera, S.E.; Wright, A.E. A novel activity from an old compound: Manzamine A reduces the metastatic potential of AsPC-1 pancreatic cancer cells and sensitizes them to TRAIL-induced apoptosis. Investig. New Drugs 2011, 29, 777-785. [CrossRef]

58. Zhang, J.S.; Koenig, A.; Harrison, A.; Ugolkov, A.V.; Fernandez-Zapico, M.E.; Couch, F.J.; Billadeau, D.D. Mutant K-Ras increases GSK-3 $\beta$ gene expression via an ETS-p300 transcriptional complex in pancreatic cancer. Oncogene 2011, 30, 3705-3715. [CrossRef]

59. Shimasaki, T.; Ishigaki, Y.; Nakamura, Y.; Takata, T.; Nakaya, N.; Nakajima, H.; Sato, I.; Zhao, X.; Kitano, A.; Kawakami, K.; et al. Glycogen synthase kinase $3 \beta$ inhibition sensitizes pancreatic cancer cells to gemcitabine. J. Gastroenterol. 2012, 47, 321-333. [CrossRef]

60. Marchand, B.; Tremblay, I.; Cagnol, S.; Boucher, M.J. Inhibition of glycogen synthase kinase-3 activity triggers an apoptotic response in pancreatic cancer cells through JNK-dependent mechanisms. Carcinogenesis 2012, 33, 529-537. [CrossRef]

61. Mamaghani, S.; Simpson, C.D.; Cao, P.M.; Cheung, M.; Chow, S.; Bandarchi, B.; Schimmer, A.D.; Hedley, D.W. Glycogen synthase kinase-3 inhibition sensitizes pancreatic cancer cells to TRAIL-induced apoptosis. PLoS ONE 2012, 7, e41102. [CrossRef] [PubMed] 
62. Kitano, A.; Shimasaki, T.; Chikano, Y.; Nakada, M.; Hirose, M.; Higashi, T.; Ishigaki, Y.; Endo, Y.; Takino, T.; Sato, H.; et al. Aberrant glycogen synthase kinase $3 \beta$ is involved in pancreatic cancer cell invasion and resistance to therapy. PLOS ONE 2013, 8, e55289. [CrossRef] [PubMed]

63. Zhang, J.S.; Herreros-Villanueva, M.; Koenig, A.; Deng, Z.; de Narvajas, A.A.; Gomez, T.S.; Meng, X.; Bujanda, L.; Ellenrieder, V.; Li, X.K.; et al. Differential activity of GSK-3 isoforms regulates NF-kB and TRAILor TNF $\alpha$ induced apoptosis in pancreatic cancer cells. Cell Death Dis. 2014, 5, e1142. [CrossRef] [PubMed]

64. Ying, X.; Jing, L.; Ma, S.; Li, Q.; Luo, X.; Pan, Z.; Feng, Y.; Feng, P. GSK3 $\beta$ mediates pancreatic cancer cell invasion in vitro via the CXCR4/MMP-2 Pathway. Cancer Cell Int. 2015, 15, 70. [CrossRef]

65. Kunnimalaiyaan, S.; Gamblin, T.C.; Kunnimalaiyaan, M. Glycogen synthase kinase-3 inhibitor AR-A014418 suppresses pancreatic cancer cell growth via inhibition of GSK-3-mediated Notch1 expression. HPB 2015, 17, 770-776. [CrossRef]

66. Ma, S.; Li, Q.; Pan, F. CXCR4 promotes GSK3 $\beta$ expression in pancreatic cancer cells via the Akt pathway. Int. J. Clin. Oncol. 2015, 20, 525-530. [CrossRef]

67. Marchand, B.; Arsenault, D.; Raymond-Fleury, A.; Boisvert, F.M.; Boucher, M.J. Glycogen synthase kinase-3 (GSK3) inhibition induces prosurvival autophagic signals in human pancreatic cancer cells. J. Biol. Chem. 2015, 290, 5592-5605. [CrossRef]

68. Baumgart, S.; Chen, N.M.; Zhang, J.S.; Billadeau, D.D.; Gaisina, I.N.; Kozikowski, A.P.; Singh, S.K.; Fink, D.; Ströbel, P.; Klindt, C.; et al. GSK-3 $\beta$ governs inflammation-induced NFATc2 signaling hubs to promote pancreatic cancer progression. Mol. Cancer Ther. 2016, 15, 491-502. [CrossRef]

69. Edderkaoui, M.; Chheda, C.; Soufi, B.; Zayou, F.; Hu, R.W.; Ramanujan, V.K.; Pan, X.; Boros, L.G.; Tajbakhsh, J.; Madhav, A.; et al. An inhibitor of GSK3B and HDACs kills pancreatic cancer cells and slows pancreatic tumor growth and metastasis in mice. Gastroenterology 2018, 155, 1985-1998. [CrossRef]

70. Nesteruk, K.; Smits, R.; Bruno, M.; Peppelenbosch, M.P.; Fuhler, G.M. Upregulated $\beta$-catenin signaling does not affect survival of pancreatic cancer cells during dual inhibition of GSK3B and HDAC. Pancreatology 2020, 20, 558-561. [CrossRef]

71. Beurel, E.; Blivet-Van Eggelpoël, M.J.; Kornprobst, M.; Moritz, S.; Delelo, R.; Paye, F.; Housset, C.; Desbois-Mouthon, C. Glycogen synthase kinase-3 inhibitors augment TRAIL-induced apoptotic death in human hepatoma cells. Biochem. Pharmacol. 2009, 77, 54-65. [CrossRef] [PubMed]

72. Shimizu, M.; Sakai, H.; Shirakami, Y.; Yasuda, Y.; Kubota, M.; Terakura, D.; Baba, A.; Ohno, T.; Hara, Y.; Tanaka, T.; et al. Preventive effects of (-)-epigallocatechin gallate on diethylnitrosamine-induced liver tumorigenesis in obese and diabetic C57BL/KsJ-db/db mice. Cancer Prev. Res 2011, 4, 396-403. [CrossRef] [PubMed]

73. Ninomiya, S.; Shimizu, M.; Imai, K.; Takai, K.; Shiraki, M.; Hara, T.; Tsurumi, H.; Ishizaki, S.; Moriwaki, H. Possible role of visfatin in hepatoma progression and the effects of branched-chain amino acids on visfatin-induced proliferation in human hepatoma cells. Cancer Prev. Res. 2011, 4, 2092-2100. [CrossRef] [PubMed]

74. Fu, K.; Pan, H.; Liu, S.; Lv, J.; Wan, Z.; Li, J.; Sun, Q.; Liang, J. Glycogen synthase kinase-3 $\beta$ regulates tumor necrosis factor-related apoptosis inducing ligand (TRAIL)-induced apoptosis via the NF- $\mathrm{B}$ pathway in hepatocellular carcinoma. Oncol. Lett. 2015, 10, 3557-3564. [CrossRef]

75. Shigeishi, H.; Biddle, A.; Gammon, L.; Emich, H.; Rodini, C.O.; Gemenetzidis, E.; Fazil, B.; Sugiyama, M.; Kamata, N.; Mackenzie, I.C. Maintenance of stem cell self-renewal in head and neck cancers requires actions of GSK3 $\beta$ influenced by CD44 and RHAMM. Stem Cells 2013, 31, 2073-2083. [CrossRef]

76. Schulz, L.; Pries, R.; Lanka, A.S.; Drenckhan, M.; Rades, D.; Wollenberg, B. Inhibition of GSK3 $\alpha / \beta$ impairs the progression of HNSCC. Oncotarget 2018, 9, 27630-27644. [CrossRef]

77. Zeng, J.; Liu, D.; Qiu, Z.; Huang, Y.; Chen, B.; Wang, L.; Xu, H.; Huang, N.; Liu, L.; Li, W. GSK3ß overexpression indicates poor prognosis and its inhibition reduces cell proliferation and survival of non-small cell lung cancer cells. PLoS ONE 2014, 9, e91231. [CrossRef]

78. Vincent, E.E.; Elder, D.J.; O’Flaherty, L.; Pardo, O.E.; Dzien, P.; Phillips, L.; Morgan, C.; Pawade, J.; May, M.T.; Sohail, M.; et al. Glycogen synthase kinase 3 protein kinase activity is frequently elevated in human non-small cell lung carcinoma and supports tumour cell proliferation. PLoS ONE 2014, 9, e114725. [CrossRef]

79. O'Flaherty, L.; Shnyder, S.D.; Cooper, P.A.; Cross, S.J.; Wakefield, J.G.; Pardo, O.E.; Seckl, M.J.; Tavaré, J.M. Tumor growth suppression using a combination of taxol-based therapy and GSK3 inhibition in non-small cell lung cancer. PLOS ONE 2019, 14, e0214610. [CrossRef] 
80. Shin, S.; Wolgamott, L.; Tcherkezian, J.; Vallabhapurapu, S.; Yu, Y.; Roux, P.P.; Yoon, S.O. Glycogen synthase kinase- $3 \beta$ positively regulates protein synthesis and cell proliferation through the regulation of translation initiation factor 4E-binding protein 1. Oncogene 2014, 33, 1690-1699. [CrossRef]

81. Gupta, C.; Kaur, J.; Tikoo, K. Regulation of MDA-MB-231 cell proliferation by GSK-3 $\beta$ involves epigenetic modifications under high glucose conditions. Exp. Cell Res. 2014, 324, 75-83. [CrossRef] [PubMed]

82. Gao, C.; Yuan, X.; Jiang, Z.; Gan, D.; Ding, L.; Sun, Y.; Zhou, J.; Xu, L.; Liu, Y.; Wang, G. Regulation of AKT phosphorylation by GSK3 $\beta$ and PTEN to control chemoresistance in breast cancer. Breast Cancer Res. Treat. 2019, 176, 291-301. [CrossRef] [PubMed]

83. Liao, X.; Zhang, L.; Thrasher, J.B.; Du, J.; Li, B. Glycogen synthase kinase- $3 \beta$ suppression eliminates tumor necrosis factor-related apoptosis-inducing ligand resistance in prostate cancer. Mol. Cancer Ther. 2003, 2, 1215-1222. [PubMed]

84. Mazor, M.; Kawano, Y.; Zhu, H.; Waxman, J.; Kypta, R.M. Inhibition of glycogen synthase kinase-3 represses androgen receptor activity and prostate cancer cell growth. Oncogene 2004, 23, 7882-7892. [CrossRef] [PubMed]

85. Sun, A.; Shanmugam, I.; Song, J.; Terranova, P.F.; Thrasher, J.B.; Li, B. Lithium suppresses cell proliferation by interrupting E2F-DNA interaction and subsequently reducing S-phase gene expression in prostate cancer. Prostate 2007, 67, 976-988. [CrossRef] [PubMed]

86. Rinnab, L.; Schütz, S.V.; Diesch, J.; Schmid, E.; Küfer, R.; Hautmann, R.E.; Spindler, K.D.; Cronauer, M.V. Inhibition of glycogen synthase kinase-3 in androgen-responsive prostate cancer cell lines: Are GSK inhibitors therapeutically useful? Neoplasia 2008, 10, 624-634. [CrossRef]

87. Schütz, S.V.; Cronauer, M.V.; Rinnab, L. Inhibition of glycogen synthase kinase- $3 \beta$ promotes nuclear export of the androgen receptor through a CRM1-dependent mechanism in prostate cancer cell lines. J. Cell Biochem. 2010, 109, 1192-1200. [CrossRef]

88. Schütz, S.V.; Schrader, A.J.; Zengerling, F.; Genze, F.; Cronauer, M.V.; Schrader, M. Inhibition of glycogen synthase kinase- $3 \beta$ counteracts ligand-independent activity of the androgen receptor in castration resistant prostate cancer. PLoS ONE 2011, 6, e25341. [CrossRef]

89. Zhu, Q.; Yang, J.; Han, S.; Liu, J.; Holzbeierlein, J.; Thrasher, J.B.; Li, B. Suppression of glycogen synthase kinase 3 activity reduces tumor growth of prostate cancer in vivo. Prostate 2011, 71, 835-845. [CrossRef]

90. Darrington, R.S.; Campa, V.M.; Walker, M.M.; Bengoa-Vergniory, N.; Gorrono-Etxebarria, I.; Uysal-Onganer, P.; Kawano, Y.; Waxman, J.; Kypta, R.M. Distinct expression and activity of GSK-3 $\alpha$ and GSK-3 $\beta$ in prostate cancer. Int. J. Cancer 2012, 131, E872-E883. [CrossRef]

91. Goc, A.; Al-Husein, B.; Katsanevas, K.; Steinbach, A.; Lou, U.; Sabbineni, H.; DeRemer, D.L.; Somanath, P.R. Targeting Src-mediated Tyr216 phosphorylation and activation of GSK-3 in prostate cancer cells inhibit prostate cancer progression in vitro and in vivo. Oncotarget 2014, 5, 775-787. [CrossRef] [PubMed]

92. Kroon, J.; in 't Veld, L.S.; Buijs, J.T.; Cheung, H.; van der Horst, G.; van der Pluijm, G. Glycogen synthase kinase- $3 \beta$ inhibition depletes the population of prostate cancer stem/progenitor-like cells and attenuates metastatic growth. Oncotarget 2014, 5, 8986-8994. [CrossRef] [PubMed]

93. Sun, A.; Li, C.; Chen, R.; Huang, Y.; Chen, Q.; Cui, X.; Liu, H.; Thrasher, J.B.; Li, B. GSK-3 $\beta$ controls autophagy by modulating LKB1-AMPK pathway in prostate cancer cells. Prostate 2016, 76, 172-183. [CrossRef] [PubMed]

94. Bilim, V.; Ougolkov, A.; Yuuki, K.; Naito, S.; Kawazoe, H.; Muto, A.; Oya, M.; Billadeau, D.; Motoyama, T.; Tomita, Y. Glycogen synthase kinase-3: A new therapeutic target in renal cell carcinoma. Br. J. Cancer 2009, 101, 2005-2014. [CrossRef]

95. Tsukigi, M.; Bilim, V.; Yuuki, K.; Ugolkov, A.; Naito, S.; Nagaoka, A.; Kato, T.; Motoyama, T.; Tomita, Y. Re-expression of miR-199a suppresses renal cancer cell proliferation and survival by targeting GSK-3 $\beta$. Cancer Lett. 2012, 315, 189-197. [CrossRef]

96. Kawazoe, H.; Bilim, V.N.; Ugolkov, A.V.; Yuuki, K.; Naito, S.; Nagaoka, A.; Kato, T.; Tomita, Y. GSK-3 inhibition in vitro and in vivo enhances antitumor effect of sorafenib in renal cell carcinoma (RCC). Biochem. Biophys. Res. Commun. 2012, 423, 490-495. [CrossRef]

97. Pal, K.; Cao, Y.; Gaisina, I.N.; Bhattacharya, S.; Dutta, S.K.; Wang, E.; Gunosewoyo, H.; Kozikowski, A.P.; Billadeau, D.D.; Mukhopadhyay, D. Inhibition of GSK-3 induces differentiation and impaired glucose metabolism in renal cancer. Mol. Cancer Ther. 2014, 13, 285-296. [CrossRef] 
98. Naito, S.; Bilim, V.; Yuuki, K.; Ugolkov, A.; Motoyama, T.; Nagaoka, A.; Kato, T.; Tomita, Y. Glycogen synthase kinase-3 $\beta$ : A prognostic marker and a potential therapeutic target in human bladder cancer. Clin. Cancer Res. 2010, 16, 5124-5132. [CrossRef]

99. Yohn, N.L.; Bingaman, C.N.; DuMont, A.L.; Yoo, L.I. Phosphatidylinositol 3'-kinase, mTOR, and glycogen synthase kinase-3 $\beta$ mediated regulation of p21 in human urothelial carcinoma cells. BMC Urol. 2011, 11, 19. [CrossRef]

100. Guo, X.; Huang, H.; Jin, H.; Xu, J.; Risal, S.; Li, J.; Li, X.; Yan, H.; Zeng, X.; Xue, L.; et al. ISO, via upregulating miR-137 transcription, inhibits GSK3 $\beta$-HSP70-MMP-2 axis, resulting in attenuating urothelial cancer invasion. Mol. Ther. Nucleic Acids 2018, 12, 337-349. [CrossRef]

101. Cao, Q.; Lu, X.; Feng, Y.J. Glycogen synthase kinase- $3 \beta$ positively regulates the proliferation of human ovarian cancer cells. Cell Res. 2006, 16, 671-677. [CrossRef] [PubMed]

102. Hilliard, T.S.; Gaisina, I.N.; Muehlbauer, A.G.; Gaisin, A.M.; Gallier, F.; Burdette, J.E. Glycogen synthase kinase $3 \beta$ inhibitors induce apoptosis in ovarian cancer cells and inhibit in-vivo tumor growth. Anticancer Drugs 2011, 22, 978-985. [CrossRef] [PubMed]

103. Guo, R.; Abdelmohsen, K.; Morin, P.J.; Gorospe, M. Novel microRNA reporter uncovers repression of let-7 by GSK-3ß. PLoS ONE 2013, 8, e66330. [CrossRef]

104. Mathuram, T.L.; Ravikumar, V.; Reece, L.M.; Sasikumar, C.S.; Cherian, K.M. Correlative studies unravelling the possible mechanism of cell death in tideglusib-treated human ovarian teratocarcinoma-derived PA-1 cells. J. Environ. Pathol. Toxicol. Oncol. 2017, 36, 321-344. [CrossRef]

105. Yin, Y.; Kizer, N.T.; Thaker, P.H.; Chiappinelli, K.B.; Trinkaus, K.M.; Goodfellow, P.J.; Ma, L. Glycogen synthase kinase $3 \beta$ inhibition as a therapeutic approach in the treatment of endometrial cancer. Int. J. Mol. Sci. 2013, 14, 16617-16637. [CrossRef]

106. Ma, C.; Zeng, C.; Jin, L.; Yang, Y.; Li, P.; Chen, L.; Wang, J. GSK3 $\beta$ mediates the carcinogenic effect of HPV16 in cervical cancer. Sci. Rep. 2015, 5, 16555. [CrossRef] [PubMed]

107. Kotliarova, S.; Pastorino, S.; Kovell, L.C.; Kotliarov, Y.; Song, H.; Zhang, W.; Bailey, R.; Maric, D.; Zenklusen, J.C.; Lee, J.; et al. Glycogen synthase kinase-3 inhibition induces glioma cell death through c-MYC, nuclear factor-kB, and glucose regulation. Cancer Res. 2008, 68, 6643-6651. [CrossRef] [PubMed]

108. Nowicki, M.O.; Dmitrieva, N.; Stein, A.M.; Cutter, J.L.; Godlewski, J.; Saeki, Y.; Nita, M.; Berens, M.E.; Sander, L.M.; Newton, H.B.; et al. Lithium inhibits invasion of glioma cells; possible involvement of glycogen synthase kinase-3. Neuro Oncol. 2008, 10, 690-699. [CrossRef] [PubMed]

109. Miyashita, K.; Kawakami, K.; Nakada, M.; Mai, W.; Shakoori, A.; Fujisawa, H.; Hayashi, Y.; Hamada, J.; Minamoto, T. Potential therapeutic effect of glycogen synthase kinase $3 \beta$ inhibition against human glioblastoma. Clin. Cancer Res. 2009, 15, 887-897. [CrossRef]

110. Korur, S.; Huber, R.M.; Sivasankaran, B.; Petrich, M.; Morin, P., Jr.; Hemmings, B.A.; Merlo, A.; Lino, M.M. GSK3 $\beta$ regulates differentiation and growth arrest in glioblastoma. PLoS ONE 2009, 4, e7443. [CrossRef]

111. Li, Y.; Lu, H.; Huang, Y.; Xiao, R.; Cai, X.; He, S.; Yan, G. Glycogen synthase kinases-3 $\beta$ controls differentiation of malignant glioma cells. Int. J. Cancer 2010, 127, 1271-1282. [CrossRef] [PubMed]

112. Williams, S.P.; Nowicki, M.O.; Liu, F.; Press, R.; Godlewski, J.; Abdel-Rasoul, M.; Kaur, B.; Fernandez, S.A.; Chiocca, E.A.; Lawler, S.E. Indirubins decrease glioma invasion by blocking migratory phenotypes in both the tumor and stromal endothelial cell compartments. Cancer Res. 2011, 71, 5374-5380. [CrossRef] [PubMed]

113. Pyko, I.V.; Nakada, M.; Sabit, H.; Teng, L.; Furuyama, N.; Hayashi, Y.; Kawakami, K.; Minamoto, T.; Fedulau, A.S.; Hamada, J. Glycogen synthase kinase $3 \beta$ inhibition sensitizes human glioblastoma cells to temozolomide by affecting O6-methylguanine DNA methyltransferase promoter methylation via c-Myc signaling. Carcinogenesis 2013, 34, 2206-2217. [CrossRef] [PubMed]

114. Zou, Q.; Hou, Y.; Shen, F.; Wang, Y. Polarized regulation of glycogen synthase kinase-3 $\beta$ is important for glioma cell invasion. PLoS ONE 2013, 8, e81814. [CrossRef]

115. Yadav, A.K.; Vashishta, V.; Joshi, N.; Taneja, P. AR-A014418 used against GSK3 $\beta$ downregulates expression of hnRNPA1 and SF2/ASF splicing factors. J. Oncol. 2014, 2014, 695325. [CrossRef]

116. Chikano, Y.; Domoto, T.; Furuta, T.; Sabit, H.; Kitano-Tamura, A.; Pyko, I.V.; Takino, T.; Sai, Y.; Hayashi, Y.; Sato, H.; et al. Glycogen synthase kinase $3 \beta$ sustains invasion of glioblastoma via the focal adhesion kinase, Rac1, and c-Jun N-terminal kinase-mediated pathway. Mol. Cancer Ther. 2015, 14, 564-574. [CrossRef] 
117. Zhou, A.; Lin, K.; Zhang, S.; Chen, Y.; Zhang, N.; Xue, J.; Wang, Z.; Aldape, K.D.; Xie, K.; Woodgett, J.R.; et al. Nuclear GSK3 $\beta$ promotes tumorigenesis by phosphorylating KDM1A and inducing its deubiquitylation by USP22. Nat. Cell Biol. 2016, 18, 954-966. [CrossRef]

118. Han, S.; Meng, L.; Jiang, Y.; Cheng, W.; Tie, X.; Xia, J.; Wu, A. Lithium enhances the antitumour effect of temozolomide against TP53 wild-type glioblastoma cells via NFAT1/FasL signalling. Br. J. Cancer 2017, 116, 1302-1311. [CrossRef]

119. Furuta, T.; Sabit, H.; Dong, Y.; Miyashita, K.; Kinoshita, M.; Uchiyama, N.; Hayashi, Y.; Hayashi, Y.; Minamoto, T.; Nakada, M. Biological basis and clinical study of glycogen synthase kinase-3 $\beta$-targeted therapy by drug repositioning for glioblastoma. Oncotarget 2017, 8, 22811-22824. [CrossRef]

120. Bruning-Richardson, A.; Droop, A.; Tams, D.; Boissinot, M.; Hayes, J.; Cheng, V.; Cockle, J.; Ismail, A.; Morton, R.; Esteves, F.; et al. Identification of transcriptional targets of GSK3 involved in glioblastoma invasion. Neuro Oncol. 2018, 20, i26. [CrossRef]

121. Sengupta, S.; Katz, S.C.; Sengupta, S.; Sampath, P. Glycogen synthase kinase 3 inhibition lowers PD-1 expression, promotes long-term survival and memory generation in antigen-specific CAR-T cells. Cancer Lett. 2018, 433, 131-139. [CrossRef] [PubMed]

122. Kitabayashi, T.; Dong, Y.; Furuta, T.; Sabit, H.; Jiapaer, S.; Zhang, J.; Zhang, G.; Hayashi, Y.; Kobayashi, M.; Domoto, T.; et al. Identification of GSK3 $\beta$ inhibitor kenpaullone as a temozolomide enhancer against glioblastoma. Sci. Rep. 2019, 9, 10049. [CrossRef]

123. Ito, H.; Watari, K.; Shibata, T.; Miyamoto, T.; Murakami, Y.; Nakahara, Y.; Izumi, H.; Wakimoto, H.; Kuwano, M.; Abe, T.; et al. Bidirectional regulation between NDRG1 and GSK3 $\beta$ controls tumor growth and is targeted by differentiation inducing factor-1 in glioblastoma. Cancer Res. 2020, 80, 234-248. [CrossRef] [PubMed]

124. Kappes, A.; Vaccaro, A.; Kunnimalaiyaan, M.; Chen, H. Lithium ions: A novel treatment for pheochromocytomas and paragangliomas. Surgery 2007, 141, 161-165. [CrossRef] [PubMed]

125. Pizarro, J.G.; Folch, J.; Esparza, J.L.; Jordan, J.; Pallàs, M.; Camins, A. A molecular study of pathways involved in the inhibition of cell proliferation in neuroblastoma B65 cells by the GSK-3 inhibitors lithium and SB-415286. J. Cell Mol. Med. 2009, 13, 3906-3917. [CrossRef]

126. Duffy, D.J.; Krstic, A.; Schwarzl, T.; Higgins, D.G.; Kolch, W. GSK3 inhibitors regulate MYCN mRNA levels and reduce neuroblastoma cell viability through multiple mechanisms, including p53 and Wnt signaling. Mol. Cancer Ther. 2014, 13, 454-467. [CrossRef]

127. Mathuram, T.L.; Ravikumar, V.; Reece, L.M.; Karthik, S.; Sasikumar, C.S.; Cherian, K.M. Tideglusib induces apoptosis in human neuroblastoma IMR32 cells, provoking sub-G0/G1 accumulation and ROS generation. Environ. Toxicol. Pharmacol. 2016, 46, 194-205. [CrossRef]

128. De Toni, F.; Racaud-Sultan, C.; Chicanne, G.; Mas, V.M.; Cariven, C.; Mesange, F.; Salles, J.P.; Demur, C.; Allouche, M.; Payrastre, B.; et al. A crosstalk between the Wnt and the adhesion-dependent signaling pathways governs the chemosensitivity of acute myeloid leukemia. Oncogene 2006, 25, 3113-3122. [CrossRef]

129. Ougolkov, A.V.; Bone, N.D.; Fernandez-Zapico, M.E.; Kay, N.E.; Billadeau, D.D. Inhibition of glycogen synthase kinase-3 activity leads to epigenetic silencing of nuclear factor $\mathrm{kB}$ target genes and induction of apoptosis in chronic lymphocytic leukemia B cells. Blood 2007, 110, 735-742. [CrossRef]

130. Holmes, T.; O’Brien, T.A.; Knight, R.; Lindeman, R.; Shen, S.; Song, E.; Symonds, G.; Dolnikov, A. Glycogen synthase kinase- $3 \beta$ inhibition preserves hematopoietic stem cell activity and inhibits leukemic cell growth. Stem Cells 2008, 26, 1288-1297. [CrossRef]

131. Wang, Z.; Smith, K.S.; Murphy, M.; Piloto, O.; Somervaille, T.C.; Cleary, M.L. Glycogen synthase kinase 3 in MLL leukaemia maintenance and targeted therapy. Nature 2008, 455, 1205-1209. [CrossRef] [PubMed]

132. Wang, Z.; Iwasaki, M.; Ficara, F.; Lin, C.; Matheny, C.; Wong, S.H.; Smith, K.S.; Cleary, M.L. GSK-3 promotes conditional association of CREB and its coactivators with MEIS1 to facilitate HOX-mediated transcription and oncogenesis. Cancer Cell 2010, 17, 597-608. [CrossRef]

133. De Toni-Costes, F.; Despeaux, M.; Bertrand, J.; Bourogaa, E.; Ysebaert, L.; Payrastre, B.; Racaud-Sultan, C. A New $\alpha 5 \beta 1$ integrin-dependent survival pathway through GSK3 $\beta$ activation in leukemic cells. PLoS ONE 2010, 5, e9807. [CrossRef] [PubMed]

134. Song, E.Y.; Palladinetti, P.; Klamer, G.; Ko, K.H.; Lindeman, R.; O’Brien, T.A.; Dolnikov, A. Glycogen synthase kinase-3 $\beta$ inhibitors suppress leukemia cell growth. Exp. Hematol. 2010, 38, 908-921. [CrossRef] [PubMed] 
135. Zhou, F.; Zhang, L.; van Laar, T.; van Dam, H.; Ten Dijke, P. GSK3 $\beta$ inactivation induces apoptosis of leukemia cells by repressing the function of c-Myb. Mol. Biol. Cell 2011, 22, 3533-3540. [CrossRef] [PubMed]

136. Bourogaa, E.; Bertrand, J.; Despeaux, M.; Jarraya, R.; Fabre, N.; Payrastre, L.; Demur, C.; Fournié, J.J.; Damak, M.; Feki, A.E.; et al. Hammada scoparia flavonoids and rutin kill adherent and chemoresistant leukemic cells. Leuk. Res. 2011, 35, 1093-1101. [CrossRef]

137. Bertrand, J.; Despeaux, M.; Joly, S.; Bourogaa, E.; Gallay, N.; Demur, C.; Bonnevialle, P.; Louache, F.; Maguer-Satta, V.; Vergnolle, N.; et al. Sex differences in the GSK3 $\beta$-mediated survival of adherent leukemic progenitors. Oncogene 2012, 31, 694-705. [CrossRef]

138. Mirlashari, M.R.; Randen, I.; Kjeldsen-Kragh, J. Glycogen synthase kinase-3 (GSK-3) inhibition induces apoptosis in leukemic cells through mitochondria-dependent pathway. Leuk. Res. 2012, 36, 499-508. [CrossRef]

139. Gupta, K.; Gulen, F.; Sun, L.; Aguilera, R.; Chakrabarti, A.; Kiselar, J.; Agarwal, M.K.; Wald, D.N. GSK3 is a regulator of RAR-mediated differentiation. Leukemia 2012, 26, 1277-1285. [CrossRef]

140. Kretzschmar, C.; Roolf, C.; Langhammer, T.S.; Sekora, A.; Pews-Davtyan, A.; Beller, M.; Frech, M.J.; Eisenlöffel, C.; Rolfs, A.; Junghanss, C. The novel arylindolylmaleimide PDA-66 displays pronounced antiproliferative effects in acute lymphoblastic leukemia cells. BMC Cancer 2014, 14, 71. [CrossRef]

141. Gupta, K.; Stefan, T.; Ignatz-Hoover, J.; Moreton, S.; Parizher, G.; Saunthararajah, Y.; Wald, D.N. GSK-3 inhibition sensitizes acute myeloid leukemia cells to 1,25D-mediated differentiation. Cancer Res. 2016, 76, 2743-2753. [CrossRef] [PubMed]

142. Hu, S.; Ueda, M.; Stetson, L.; Ignatz-Hoover, J.; Moreton, S.; Chakrabarti, A.; Xia, Z.; Karan, G.; de Lima, M.; Agrawal, M.K.; et al. A novel glycogen synthase kinase-3 inhibitor optimized for acute myeloid leukemia differentiation activity. Mol. Cancer Ther. 2016, 15, 1485-1494. [CrossRef] [PubMed]

143. Parameswaran, R.; Ramakrishnan, P.; Moreton, S.A.; Xia, Z.; Hou, Y.; Lee, D.A.; Gupta, K.; de Lima, M.; Beck, R.C.; Wald, D.N. Repression of GSK3 restores NK cell cytotoxicity in AML patients. Nat. Commun. 2016, 7, 11154. [CrossRef] [PubMed]

144. Cichocki, F.; Valamehr, B.; Bjordahl, R.; Zhang, B.; Rezner, B.; Rogers, P.; Gaidarova, S.; Moreno, S.; Tuininga, K.; Dougherty, P.; et al. GSK3 inhibition drives maturation of NK cells and enhances their antitumor activity. Cancer Res. 2017, 77, 5664-5675. [CrossRef] [PubMed]

145. Zhou, Y.; Uddin, S.; Zimmerman, T.; Kang, J.A.; Ulaszek, J.; Wickrema, A. Growth control of multiple myeloma cells through inhibition of glycogen synthase kinase-3. Leuk. Lymphoma 2008, 49, 1945-1953. [CrossRef] [PubMed]

146. Kunnimalaiyaan, M.; Vaccaro, A.M.; Ndiaye, M.A.; Chen, H. Inactivation of glycogen synthase kinase-3 $\beta$, a downstream target of the raf-1 pathway, is associated with growth suppression in medullary thyroid cancer cells. Mol. Cancer Ther. 2007, 6, 1151-1158. [CrossRef]

147. Adler, J.T.; Cook, M.; Luo, Y.; Pitt, S.C.; Ju, J.; Li, W.; Shen, B.; Kunnimalaiyaan, M.; Chen, H. Tautomycetin and tautomycin suppress the growth of medullary thyroid cancer cells via inhibition of glycogen synthase kinase-3ß. Mol. Cancer Ther. 2009, 8, 914-920. [CrossRef]

148. Chen, J.Y.; Cook, M.R.; Pinchot, S.N.; Kunnimalaiyaan, M.; Chen, H. MG-132 inhibits carcinoid growth and alters the neuroendocrine phenotype. J. Surg. Res. 2010, 158, 15-19. [CrossRef]

149. Aristizabal Prada, E.T.; Weis, C.; Orth, M.; Lauseker, M.; Spöttl, G.; Maurer, J.; Grabowski, P.; Grossman, A.; Auernhammer, C.J.; Nölting, S. GSK3 $\alpha / \beta$ : A novel therapeutic target for neuroendocrine tumors. Neuroendocrinology 2018, 106, 335-351. [CrossRef]

150. Aristizabal Prada, E.T.; Spöttl, G.; Maurer, J.; Lauseker, M.; Koziolek, E.J.; Schrader, J.; Grossman, A.; Pacak, K.; Beuschlein, F.; Auernhammer, C.J.; et al. The role of GSK3 and its reversal with GSK3 antagonism in everolimus resistance. Endocr. Relat. Cancer 2018, 25, 893-908. [CrossRef]

151. Tang, Q.L.; Xie, X.B.; Wang, J.; Chen, Q.; Han, A.J.; Zou, C.Y.; Yin, J.Q.; Liu, D.W.; Liang, Y.; Zhao, Z.Q.; et al. Glycogen synthase kinase-3 $\beta, \mathrm{NF}-\mathrm{kB}$ signaling, and tumorigenesis of human osteosarcoma. J. Natl. Cancer Inst. 2012, 104, 749-763. [CrossRef] [PubMed]

152. Shimozaki, S.; Yamamoto, N.; Domoto, T.; Nishida, H.; Hayashi, K.; Kimura, H.; Takeuchi, A.; Miwa, S.; Igarashi, K.; Kato, T.; et al. Efficacy of glycogen synthase kinase- $3 \beta$ targeting against osteosarcoma via activation of $\beta$-catenin. Oncotarget 2016, 7, 77038-77051. [CrossRef] [PubMed] 
153. Nishimura, H.; Nakamura, O.; Yamagami, Y.; Mori, M.; Horie, R.; Fukuoka, N.; Yamamoto, T. GSK-3 inhibitor inhibits cell proliferation and induces apoptosis in human osteosarcoma cells. Oncol. Rep. 2016, 35, 2348-2354. [CrossRef] [PubMed]

154. Lu, K.; Wang, X.; Chen, Y.; Liang, D.; Luo, H.; Long, L.; Hu, Z.; Bao, J. Identification of two potential glycogen synthase kinase $3 \beta$ inhibitors for the treatment of osteosarcoma. Acta Biochim. Biophys. Sin. 2018, 50, 456-464. [CrossRef] [PubMed]

155. Zeng, F.Y.; Dong, H.; Cui, J.; Liu, L.; Chen, T. Glycogen synthase kinase 3 regulates PAX3-FKHR-mediated cell proliferation in human alveolar rhabdomyosarcoma cells. Biochem. Biophys. Res. Commun. 2010, 391, 1049-1055. [CrossRef]

156. Chen, E.Y.; DeRan, M.T.; Ignatius, M.S.; Grandinetti, K.B.; Clagg, R.; McCarthy, K.M.; Lobbardi, R.M.; Brockmann, J.; Keller, C.; Wu, X.; et al. Glycogen synthase kinase 3 inhibitors induce the canonical WNT/ $\beta$-catenin pathway to suppress growth and self-renewal in embryonal rhabdomyosarcoma. Proc. Natl. Acad. Sci. USA 2014, 111, 5349-5354. [CrossRef]

157. Abe, K.; Yamamoto, N.; Domoto, T.; Bolidong, D.; Hayashi, K.; Takeuchi, A.; Miwa, S.; Igarashi, K.; Inatani, H.; Aoki, Y.; et al. Glycogen synthase kinase $3 \beta$ as a potential therapeutic target in synovial sarcoma and fibrosarcoma. Cancer Sci. 2020, 111, 429-440. [CrossRef]

158. Smalley, K.S.; Contractor, R.; Haass, N.K.; Kulp, A.N.; Atilla-Gokcumen, G.E.; Williams, D.S.; Bregman, H.; Flaherty, K.T.; Soengas, M.S.; Meggers, E.; et al. An organometallic protein kinase inhibitor pharmacologically activates p53 and induces apoptosis in human melanoma cells. Cancer Res. 2007, 67, 209-217. [CrossRef]

159. Kubic, J.D.; Mascarenhas, J.B.; Iizuka, T.; Wolfgeher, D.; Lang, D. GSK-3 promotes cell survival, growth, and PAX3 levels in human melanoma cells. Mol. Cancer Res. 2012, 10, 1065-1076. [CrossRef]

160. Atkinson, J.M.; Rank, K.B.; Zeng, Y.; Capen, A.; Yadav, V.; Manro, J.R.; Engler, T.A.; Chedid, M. Activating the Wnt/ $\beta$-catenin pathway for the treatment of melanoma-application of LY2090314, a novel selective inhibitor of glycogen synthase kinase-3. PLOS ONE 2015, 10, e0125028. [CrossRef]

161. Minamoto, T.; Kotake, M.; Nakada, M.; Shimasaki, T.; Motoo, Y.; Kawakami, K. Distinct pathologic role for glycogen synthase kinase $3 \beta$ in colorectal cancer progression. In Colorectal Cancer Biology-From Genes to Tumor; IntechOpen: London, UK, 2012. [CrossRef]

162. Garcea, G.; Manson, M.M.; Neal, C.P.; Pattenden, C.J.; Sutton, C.D.; Dennison, A.R.; Berry, D.P. Glycogen synthase kinase-3 $\beta$; a new target in pancreatic cancer? Curr. Cancer Drug Targets 2007, 7, 209-215. [CrossRef]

163. Motoo, Y.; Shimasaki, T.; Ishigaki, Y.; Nakajima, H.; Kawakami, K.; Minamoto, T. Metabolic disorder, inflammation, and deregulated molecular pathways converging in pancreatic cancer development: Implications for new therapeutic strategies. Cancers 2011, 3, 446-460. [CrossRef]

164. Shimasaki, T.; Kitano, A.; Motoo, Y.; Minamoto, T. Aberrant glycogen synthase kinase $3 \beta$ in the development of pancreatic cancer. J. Carcinog. 2012, 11, 15. [CrossRef] [PubMed]

165. Zhang, Q.; Bhojani, M.S.; Ben-Josef, E.; Spalding, A.C.; Kuick, R.; Sun, Y.; Morgan, M.A. Glycogen synthase kinase $3 \beta$ in pancreatic cancer and its implications in chemotherapy and radiation therapy. J. Carcinog. Mutagenes. 2013, 4, 147. [CrossRef]

166. Li, B.; Thrasher, J.B.; Terranova, P. Glycogen synthase kinase-3: A potential preventive target for prostate cancer management. Urol. Oncol. 2015, 33, 456-463. [CrossRef] [PubMed]

167. Nakada, M.; Minamoto, T.; Pyko, I.; Hayashi, Y.; Hamada, J. The pivotal role of GSK3 $\beta$ in glioma biology. In Molecular Targets of CNS Tumors; IntechOpen: London, UK, 2011. [CrossRef]

168. Nakada, M.; Furuta, T.; Hayashi, Y.; Minamoto, T.; Hamada, J. The strategy for enhancing temozolomide against malignant glioma. Front. Oncol. 2012, 2, 98. [CrossRef] [PubMed]

169. Atkins, R.J.; Stylli, S.S.; Luwor, R.B.; Kaye, A.H.; Hovens, C.M. Glycogen synthase kinase-3 $\beta$ (GSK-3 $\beta$ ) and its dysregulation in glioblastoma multiforme. J. Clin. Neurosci. 2013, 20, 1185-1192. [CrossRef] [PubMed]

170. Holmes, T.; O'Brien, T.A.; Knight, R.; Lindeman, R.; Symonds, G.; Dolnikov, A. The role of glycogen synthase kinase-3 $\beta$ in normal haematopoiesis, angiogenesis and leukaemia. Curr. Med. Chem. 2008, 15, 1493-1499. [CrossRef]

171. Birch, N.W.; Zeleznik-Le, N.J. Glycogen synthase kinase-3 and leukemia: Restoring the balance. Cancer Cell 2010, 17, 529-531. [CrossRef]

172. McCubrey, J.A.; Steelman, L.S.; Bertrand, F.E.; Davis, N.M.; Abrams, S.L.; Montalto, G.; D' Assoro, A.B.; Libra, M.; Nicoletti, F.; Maestro, R.; et al. Multifaceted roles of GSK-3 and Wnt/ $\beta$-catenin in hematopoiesis and leukemogenesis: Opportunities for therapeutic intervention. Leukemia 2014, 28, 15-33. [CrossRef] 
173. Bang, D.; Wilson, W.; Ryan, M.; Yeh, J.J.; Baldwin, A.S. GSK-3 $\alpha$ promotes oncogenic KRAS function in pancreatic cancer via TAK1-TAB stabilization and regulation of noncanonical NF-кB. Cancer Discov. 2013, 3, 690-703. [CrossRef] [PubMed]

174. Banerji, V.; Frumm, S.M.; Ross, K.N.; Li, L.S.; Schinzel, A.C.; Hahn, C.K.; Kakoza, R.M.; Chow, K.T.; Ross, L.; Alexe, G.; et al. The intersection of genetic and chemical genomic screens identifies GSK-3 $\alpha$ as a target in human acute myeloid leukemia. J. Clin. Investig. 2012, 122, 935-947. [CrossRef] [PubMed]

175. Wagner, F.F.; Benajiba, L.; Campbell, A.J.; Weïwer, M.; Sacher, J.R.; Gale, J.P.; Ross, L.; Puissant, A.; Alexe, G.; Conway, A.; et al. Exploiting an Asp-Glu "switch" in glycogen synthase kinase 3 to design paralog-selective inhibitors for use in acute myeloid leukemia. Sci. Transl. Med. 2018, 10. [CrossRef] [PubMed]

176. Duda, P.; Akula, S.M.; Abrams, S.L.; Steelman, L.S.; Martelli, A.M.; Cocco, L.; Ratti, S.; Candido, S.; Libra, M.; Montalto, G.; et al. Targeting GSK3 and associated signaling pathways involved in cancer. Cells 2020, 9, 1110. [CrossRef]

177. Rizzieri, D.A.; Cooley, S.; Odenike, O.; Moonan, L.; Chow, K.H.; Jackson, K.; Wang, X.; Brail, L.; Borthakur, G. An open-label phase 2 study of glycogen synthase kinase-3 inhibitor LY2090314 in patients with acute leukemia. Leuk. Lymphoma 2016, 57, 1800-1806. [CrossRef]

178. Gray, J.E.; Infante, J.R.; Brail, L.H.; Simon, G.R.; Cooksey, J.F.; Jones, S.F.; Farrington, D.L.; Yeo, A.; Jackson, K.A.; Chow, K.H.; et al. A first-in-human phase I dose-escalation, pharmacokinetic, and pharmacodynamic evaluation of intravenous LY2090314, a glycogen synthase kinase 3 inhibitor, administered in combination with pemetrexed and carboplatin. Investig. New Drugs 2015, 33, 1187-1196. [CrossRef]

179. Hanahan, D.; Weinberg, R.A. Hallmarks of cancer: The next generation. Cell 2011, 144, 646-674. [CrossRef]

180. Fuchs, S.Y.; Ougolkov, A.V.; Spiegelman, V.S.; Minamoto, T. Oncogenic $\beta$-catenin signaling networks in colorectal cancer. Cell Cycle 2005, 4, 1522-1539. [CrossRef]

181. Zhan, T.; Rindtorff, N.; Boutros, M. Wnt signaling in cancer. Oncogene 2017, 36, 1461-1473. [CrossRef]

182. Albuquerque, C.; Breukel, C.; van der Luijt, R.; Fidalgo, P.; Lage, P.; Slors, F.J.; Leitão, C.N.; Fodde, R.; Smits, R. The 'just-right' signaling model: APC somatic mutations are selected based on a specific level of activation of the $\beta$-catenin signaling cascade. Hum. Mol. Genet. 2002, 11, 1549-1560. [CrossRef]

183. Kim, K.; Pang, K.M.; Evans, M.; Hay, E.D. Overexpression of $\beta$-catenin induces apoptosis independent of its transactivation function with LEF-1 or the involvement of major G1 cell cycle regulators. Mol. Biol. Cell 2000, 11, 3509-3523. [CrossRef]

184. Cho, Y.J.; Yoon, J.; Ko, Y.S.; Kim, S.Y.; Cho, S.J.; Kim, W.H.; Park, J.W.; Youn, H.D.; Kim, J.H.; Lee, B.L. Glycogen synthase kinase- $3 \beta$ does not correlate with the expression and activity of $\beta$-catenin in gastric cancer. APMIS 2010, 118, 782-790. [CrossRef] [PubMed]

185. Al-Aynati, M.M.; Radulovich, N.; Riddell, R.H.; Tsao, M.S. Epithelial-cadherin and $\beta$-catenin expression changes in pancreatic intraepithelial neoplasia. Clin. Cancer Res. 2004, 10, 1235-1240. [CrossRef] [PubMed]

186. Erdal, E.; Ozturk, N.; Cagatay, T.; Eksioglu-Demiralp, E.; Ozturk, M. Lithium-mediated downregulation of PKB/Akt and cyclin E with growth inhibition in hepatocellular carcinoma cells. Int. J. Cancer 2005, 115, 903-910. [CrossRef] [PubMed]

187. Brack, A.S.; Conboy, I.M.; Conboy, M.J.; Shen, J.; Rando, T.A. A temporal switch from notch to Wnt signaling in muscle stem cells is necessary for normal adult myogenesis. Cell Stem Cell 2008, 2, 50-59. [CrossRef] [PubMed]

188. Dominguez-Brauer, C.; Thu, K.L.; Mason, J.M.; Blaser, H.; Bray, M.R.; Mak, T.W. Targeting mitosis in cancer: Emerging strategies. Mol. Cell 2015, 60, 524-536. [CrossRef]

189. Gönczy, P. Centrosomes and cancer: Revisiting a long-standing relationship. Nat. Rev. Cancer 2015, 15, 639-652. [CrossRef]

190. Mc Gee, M.M. Targeting the mitotic catastrophe signaling pathway in cancer. Mediat. Inflamm. 2015, 2015, 146282. [CrossRef]

191. Ferreira, L.M.; Hebrant, A.; Dumont, J.E. Metabolic reprogramming of the tumor. Oncogene 2012, 31, 3999-4011. [CrossRef]

192. Cantor, J.R.; Sabatini, D.M. Cancer cell metabolism: One hallmark, many faces. Cancer Discov. 2012, 2, 881-898. [CrossRef]

193. Lu, J. The Warburg metabolism fuels tumor metastasis. Cancer Metastasis Rev. 2019, 38, 157-164. [CrossRef] [PubMed] 
194. Ohashi, S.; Miyamoto, S.; Kikuchi, O.; Goto, T.; Amanuma, Y.; Muto, M. Recent advances from basic and clinical studies of esophageal squamous cell carcinoma. Gastroenterology 2015, 149, 1700-1715. [CrossRef] [PubMed]

195. Stuelten, C.H.; Parent, C.A.; Montell, D.J. Cell motility in cancer invasion and metastasis: Insights from simple model organisms. Nat. Rev. Cancer 2018, 18, 296-312. [CrossRef]

196. Welch, D.R.; Hurst, D.R. Defining the hallmarks of metastasis. Cancer Res. 2019, 79, 3011-3027. [CrossRef] [PubMed]

197. Nieto, M.A.; Huang, R.Y.; Jackson, R.A.; Thiery, J.P. EMT: 2016. Cell 2016, 166, 21-45. [CrossRef]

198. Brabletz, T.; Kalluri, R.; Nieto, M.A.; Weinberg, R.A. EMT in cancer. Nat. Rev. Cancer 2018, 18, $128-134$. [CrossRef]

199. Bunz, F. EMT and back again: Visualizing the dynamic phenotypes of metastasis. Cancer Res. 2020, 80, 153-155. [CrossRef]

200. Williams, E.D.; Gao, D.; Redfern, A.; Thompson, E.W. Controversies around epithelial-mesenchymal plasticity in cancer metastasis. Nat. Rev. Cancer 2019, 19, 716-732. [CrossRef]

201. Bachelder, R.E.; Yoon, S.O.; Franci, C.; de Herreros, A.G.; Mercurio, A.M. Glycogen synthase kinase-3 is an endogenous inhibitor of Snail transcription: Implications for the epithelial-mesenchymal transition. J. Cell Biol. 2005, 168, 29-33. [CrossRef]

202. Sun, T.; Rodriguez, M.; Kim, L. Glycogen synthase kinase 3 in the world of cell migration. Dev. Growth Differ. 2009, 51, 735-742. [CrossRef]

203. Kleeff, J.; Korc, M.; Apte, M.; La Vecchia, C.; Johnson, C.D.; Biankin, A.V.; Neale, R.E.; Tempero, M.; Tuveson, D.A.; Hruban, R.H.; et al. Pancreatic cancer. Nat. Rev. Dis. Primers 2016, 2, 16022. [CrossRef] [PubMed]

204. Lapointe, S.; Perry, A.; Butowski, N.A. Primary brain tumours in adults. The Lancet 2018, 392, $432-446$. [CrossRef]

205. Machesky, L.M. Lamellipodia and filopodia in metastasis and invasion. FEBS Lett. 2008, 582, $2102-2111$. [CrossRef]

206. Paz, H.; Pathak, N.; Yang, J. Invading one step at a time: The role of invadopodia in tumor metastasis. Oncogene 2014, 33, 4193-4202. [CrossRef]

207. Holohan, C.; Van Schaeybroeck, S.; Longley, D.B.; Johnston, P.G. Cancer drug resistance: An evolving paradigm. Nat. Rev. Cancer 2013, 13, 714-726. [CrossRef] [PubMed]

208. Vasan, N.; Baselga, J.; Hyman, D.M. A view on drug resistance in cancer. Nature 2019, 575, 299-309. [CrossRef]

209. Alexander, S.; Friedl, P. Cancer invasion and resistance: Interconnected processes of disease progression and therapy failure. Trends Mol. Med. 2012, 18, 13-26. [CrossRef]

210. Al-Lazikani, B.; Banerji, U.; Workman, P. Combinatorial drug therapy for cancer in the post-genomic era. Nat. Biotechnol. 2012, 30, 679-692. [CrossRef]

211. Papadatos-Pastos, D.; De Miguel Luken, M.J.; Yap, T.A. Combining targeted therapeutics in the era of precision medicine. Br. J. Cancer 2015, 112, 1-3. [CrossRef]

212. Batlle, E.; Clevers, H. Cancer stem cells revisited. Nat. Med. 2017, 23, 1124-1134. [CrossRef]

213. Soteriou, D.; Fuchs, Y. A matter of life and death: Stem cell survival in tissue regeneration and tumour formation. Nat. Rev. Cancer 2018, 18, 187-201. [CrossRef] [PubMed]

214. Lytle, N.K.; Barber, A.G.; Reya, T. Stem cell fate in cancer growth, progression and therapy resistance. Nat. Rev. Cancer 2018, 18, 669-680. [CrossRef] [PubMed]

215. Clarke, M.F. Clinical and therapeutic implications of cancer stem cells. N. Engl. J. Med. 2019, 380, $2237-2245$. [CrossRef]

216. Marcucci, F.; Rumio, C.; Lefoulon, F. Anti-cancer stem-like cell compounds in clinical development -An overview and critical appraisal. Front. Oncol. 2016, 6, 115. [CrossRef] [PubMed]

217. Kaiser, J. The cancer stem cell gamble. Science 2015, 347, 226-229. [CrossRef] [PubMed]

218. Prestegarden, L.; Enger, P. Cancer stem cells in the central nervous system-A critical review. Cancer Res. 2010, 70, 8255-8258. [CrossRef]

219. Bahr, C.; Correia, N.C.; Trumpp, A. Stem cells make leukemia grow again. EMBO J. 2017, 36, $2667-2669$. [CrossRef] 
220. Sato, N.; Meijer, L.; Skaltsounis, L.; Greengard, P.; Brivanlou, A.H. Maintenance of pluripotency in human and mouse embryonic stem cells through activation of Wnt signaling by a pharmacological GSK-3-specific inhibitor. Nat. Med. 2004, 10, 55-63. [CrossRef]

221. Trowbridge, J.J.; Xenocostas, A.; Moon, R.T.; Bhatia, M. Glycogen synthase kinase-3 is an in vivo regulator of hematopoietic stem cell repopulation. Nat. Med. 2006, 12, 89-98. [CrossRef]

222. Ko, K.H.; Holmes, T.; Palladinetti, P.; Song, E.; Nordon, R.; O’Brien, T.A.; Dolnikov, A. GSK-3 $\beta$ inhibition promotes engraftment of ex vivo-expanded hematopoietic stem cells and modulates gene expression. Stem Cells 2011, 29, 108-118. [CrossRef]

223. Lapid, K.; Itkin, T.; D’Uva, G.; Ovadya, Y.; Ludin, A.; Caglio, G.; Kalinkovich, A.; Golan, K.; Porat, Z.; Zollo, M.; et al. GSK3 $\beta$ regulates physiological migration of stem/progenitor cells via cytoskeletal rearrangement. J. Clin. Investig. 2013, 123, 1705-1717. [CrossRef] [PubMed]

224. Farkona, S.; Diamandis, E.P.; Blasutig, I.M. Cancer immunotherapy: The beginning of the end of cancer? BMC Med. 2016, 14, 73. [CrossRef] [PubMed]

225. Hu, W.; Wang, G.; Huang, D.; Sui, M.; Xu, Y. Cancer immunotherapy based on natural killer cells: Current progress and new opportunities. Front. Immunol. 2019, 10, 1205. [CrossRef] [PubMed]

226. Sanchez-Correa, B.; Lopez-Sejas, N.; Duran, E.; Labella, F.; Alonso, C.; Solana, R.; Tarazona, R. Modulation of NK cells with checkpoint inhibitors in the context of cancer immunotherapy. Cancer Immunol. Immunother. 2019, 68, 861-870. [CrossRef]

227. Suen, W.C.; Lee, W.Y.; Leung, K.T.; Pan, X.H.; Li, G. Natural killer cell-based cancer immunotherapy: A review on 10 years completed clinical trials. Cancer Investig. 2018, 36, 431-457. [CrossRef]

228. Ben-Shmuel, A.; Biber, G.; Barda-Saad, M. Unleashing natural killer cells in the tumor microenvironment -The next generation of immunotherapy? Front. Immunol. 2020, 11, 275. [CrossRef]

229. Gattinoni, L.; Zhong, X.S.; Palmer, D.C.; Ji, Y.; Hinrichs, C.S.; Yu, Z.; Wrzesinski, C.; Boni, A.; Cassard, L.; Garvin, L.M.; et al. Wnt signaling arrests effector T cell differentiation and generates CD8 ${ }^{+}$memory stem cells. Nat. Med. 2009, 15, 808-813. [CrossRef]

230. June, C.H.; Sadelain, M. Chimeric antigen receptor therapy. N. Engl. J. Med. 2018, 379, 64-73. [CrossRef]

231. Ghimire, S.; Weber, D.; Mavin, E.; Wang, X.N.; Dickinson, A.M.; Holler, E. Pathophysiology of GvHD and other HSCT-related major complications. Front. Immunol. 2017, 8, 79. [CrossRef]

232. Kanfar, S.; Al-Anazi, K. Autologous graft versus host disease: An updated review. Ann. Stem Cells Regen. Med. 2018, 1, 1002.

233. Klamer, G.; Shen, S.; Song, E.; Rice, A.M.; Knight, R.; Lindeman, R.; O’Brien, T.A.; Dolnikov, A. GSK3 inhibition prevents lethal GVHD in mice. Exp. Hematol. 2013, 41, 39-55.e10. [CrossRef] [PubMed]

234. Shen, S.; Klamer, G.; Xu, N.; O’Brien, T.A.; Dolnikov, A. GSK-3 $\beta$ inhibition preserves naive T cell phenotype in bone marrow reconstituted mice. Exp. Hematol. 2013, 41, 1016-1027.e1011. [CrossRef] [PubMed]

235. Dolnikov, A.; Xu, N.; Shen, S.; Song, E.; Holmes, T.; Klamer, G.; O’Brien, T.A. GSK-3 $\beta$ inhibition promotes early engraftment of ex vivo-expanded haematopoietic stem cells. Cell Prolif. 2014, 47, 113-123. [CrossRef] [PubMed]

236. Bloom, J.; Brandt, J. Chapter 11: Toxic responses of the blood. In Casarett's \& Doull's Toxicology: The Basic Science of Poisons; The McGraw-Hill Companies: New York, NY, USA, 2008; pp. 455-484.

237. Ziepert, M.; Schmits, R.; Trümper, L.; Pfreundschuh, M.; Loeffler, M. Prognostic factors for hematotoxicity of chemotherapy in aggressive non-Hodgkin's lymphoma. Ann. Oncol. 2008, 19, 752-762. [CrossRef] [PubMed]

238. Barcellos-Hoff, M.H.; Park, C.; Wright, E.G. Radiation and the microenvironment-Tumorigenesis and therapy. Nat. Rev. Cancer 2005, 5, 867-875. [CrossRef]

239. Shukla, P.; Singh, R. Potential pharmacological interventions against hematotoxicity: An overview. Expert Rev. Hematol. 2015, 8, 505-514. [CrossRef]

240. Barry, F.A.; Graham, G.J.; Fry, M.J.; Gibbins, J.M. Regulation of glycogen synthase kinase 3 in human platelets: A possible role in platelet function? FEBS Lett. 2003, 553, 173-178. [CrossRef]

241. Ewertz, M.; Qvortrup, C.; Eckhoff, L. Chemotherapy-induced peripheral neuropathy in patients treated with taxanes and platinum derivatives. Acta Oncol. 2015, 54, 587-591. [CrossRef] [PubMed]

242. Carozzi, V.A.; Canta, A.; Chiorazzi, A. Chemotherapy-induced peripheral neuropathy: What do we know about mechanisms? Neurosci. Lett. 2015, 596, 90-107. [CrossRef] [PubMed]

243. Hou, S.; Huh, B.; Kim, H.K.; Kim, K.H.; Abdi, S. Treatment of chemotherapy-induced peripheral neuropathy: Systematic review and recommendations. Pain Phys. 2018, 21, 571-592. 
244. Hu, S.; Huang, K.M.; Adams, E.J.; Loprinzi, C.L.; Lustberg, M.B. Recent developments of novel pharmacologic therapeutics for prevention of chemotherapy-induced peripheral neuropathy. Clin. Cancer Res. 2019, 25, 6295-6301. [CrossRef] [PubMed]

245. Cross, D.A.; Culbert, A.A.; Chalmers, K.A.; Facci, L.; Skaper, S.D.; Reith, A.D. Selective small-molecule inhibitors of glycogen synthase kinase-3 activity protect primary neurones from death. J. Neurochem. 2001, 77, 94-102. [CrossRef] [PubMed]

246. Reinhardt, L.; Kordes, S.; Reinhardt, P.; Glatza, M.; Baumann, M.; Drexler, H.C.A.; Menninger, S.; Zischinsky, G.; Eickhoff, J.; Fröb, C.; et al. Dual inhibition of GSK3 $\beta$ and CDK5 protects the cytoskeleton of neurons from neuroinflammatory-mediated degeneration in vitro and in vivo. Stem Cell Rep. 2019, 12, 502-517. [CrossRef] [PubMed]

247. Eom, T.Y.; Roth, K.A.; Jope, R.S. Neural precursor cells are protected from apoptosis induced by trophic factor withdrawal or genotoxic stress by inhibitors of glycogen synthase kinase 3. J. Biol. Chem. 2007, 282, 22856-22864. [CrossRef] [PubMed]

248. Mo, M.; Erdelyi, I.; Szigeti-Buck, K.; Benbow, J.H.; Ehrlich, B.E. Prevention of paclitaxel-induced peripheral neuropathy by lithium pretreatment. FASEB J. 2012, 26, 4696-4709. [CrossRef] [PubMed]

249. Anderson, V.A.; Godber, T.; Smibert, E.; Weiskop, S.; Ekert, H. Cognitive and academic outcome following cranial irradiation and chemotherapy in children: A longitudinal study. Br. J. Cancer 2000, 82, 255-262. [CrossRef]

250. Surma-aho, O.; Niemelä, M.; Vilkki, J.; Kouri, M.; Brander, A.; Salonen, O.; Paetau, A.; Kallio, M.; Pyykkönen, J.; Jääskeläinen, J. Adverse long-term effects of brain radiotherapy in adult low-grade glioma patients. Neurology 2001, 56, 1285-1290. [CrossRef]

251. Thotala, D.K.; Hallahan, D.E.; Yazlovitskaya, E.M. Inhibition of glycogen synthase kinase $3 \beta$ attenuates neurocognitive dysfunction resulting from cranial irradiation. Cancer Res. 2008, 68, 5859-5868. [CrossRef]

252. Yang, E.S.; Nowsheen, S.; Wang, T.; Thotala, D.K.; Xia, F. Glycogen synthase kinase $3 \beta$ inhibition enhances repair of DNA double-strand breaks in irradiated hippocampal neurons. Neuro Oncol. 2011, 13, 459-470. [CrossRef]

253. Waber, D.P. Central nervous system late effects: A new frontier? Pediatric Blood Cancer 2011, 57, $355-356$. [CrossRef]

254. Elens, I.; Deprez, S.; Danckaerts, M.; Bijttebier, P.; Labarque, V.; Uyttebroeck, A.; Van Gool, S.; D’Hooge, R.; Lemiere, J. Neurocognitive sequelae in adult childhood leukemia survivors related to levels of phosphorylated tau. J. Natl. Cancer Inst. 2017, 109. [CrossRef] [PubMed]

255. Henson, L.A.; Maddocks, M.; Evans, C.; Davidson, M.; Hicks, S.; Higginson, I.J. Palliative care and the management of common distressing symptoms in advanced cancer: Pain, breathlessness, nausea and vomiting, and fatigue. J. Clin. Oncol. 2020, 38, 905-914. [CrossRef] [PubMed]

256. Degenhardt, L.; Grebely, J.; Stone, J.; Hickman, M.; Vickerman, P.; Marshall, B.D.L.; Bruneau, J.; Altice, F.L.; Henderson, G.; Rahimi-Movaghar, A.; et al. Global patterns of opioid use and dependence: Harms to populations, interventions, and future action. The Lancet 2019, 394, 1560-1579. [CrossRef]

257. Li, Y.; Eitan, S.; Wu, J.; Evans, C.J.; Kieffer, B.; Sun, X.; Polakiewicz, R.D. Morphine induces desensitization of insulin receptor signaling. Mol. Cell Biol. 2003, 23, 6255-6266. [CrossRef]

258. Muller, D.L.; Unterwald, E.M. In vivo regulation of extracellular signal-regulated protein kinase (ERK) and protein kinase B (Akt) phosphorylation by acute and chronic morphine. J. Pharmacol. Exp. Ther. 2004, 310, 774-782. [CrossRef]

259. Johnston, I.N.; Westbrook, R.F. Inhibition of morphine analgesia by lithium: Role of peripheral and central opioid receptors. Behav. Brain Res. 2004, 151, 151-158. [CrossRef]

260. Parkitna, J.R.; Obara, I.; Wawrzczak-Bargiela, A.; Makuch, W.; Przewlocka, B.; Przewlocki, R. Effects of glycogen synthase kinase $3 \beta$ and cyclin-dependent kinase 5 inhibitors on morphine-induced analgesia and tolerance in rats. J. Pharmacol. Exp. Ther. 2006, 319, 832-839. [CrossRef]

261. Liao, W.W.; Tsai, S.Y.; Liao, C.C.; Chen, K.B.; Yeh, G.C.; Chen, J.Y.; Wen, Y.R. Coadministration of glycogen-synthase kinase 3 inhibitor with morphine attenuates chronic morphine-induced analgesic tolerance and withdrawal syndrome. J. Chin. Med. Assoc. 2014, 77, 31-37. [CrossRef]

262. The ESMO/European Sarcoma Network Working Group. Bone sarcomas: ESMO Clinical Practice Guidelines for diagnosis, treatment and follow-up. Ann. Oncol. 2014, 25 (Suppl. 3), iii113-iii123. [CrossRef] 
263. Gilbert, N.F.; Cannon, C.P.; Lin, P.P.; Lewis, V.O. Soft-tissue sarcoma. J. Am. Acad. Orthopeadic Surg. 2009, 17, 40-47. [CrossRef]

264. Botter, S.M.; Neri, D.; Fuchs, B. Recent advances in osteosarcoma. Curr. Opin. Pharmacol. 2014, 16, 15-23. [CrossRef]

265. Kawai, A.; Yonemori, K.; Takahashi, S.; Araki, N.; Ueda, T. Systemic therapy for soft tissue sarcoma: Proposals for the optimal use of pazopanib, trabectedin, and eribulin. Adv. Ther. 2017, 34, 1556-1571. [CrossRef] [PubMed]

266. Kansara, M.; Teng, M.W.; Smyth, M.J.; Thomas, D.M. Translational biology of osteosarcoma. Nat. Rev. Cancer 2014, 14, 722-735. [CrossRef] [PubMed]

267. Lim, J.; Poulin, N.M.; Nielsen, T.O. New strategies in sarcoma: Linking genomic and immunotherapy approaches to molecular subtype. Clin. Cancer Res. 2015, 21, 4753-4759. [CrossRef] [PubMed]

268. Dufresne, A.; Brahmi, M.; Karanian, M.; Blay, J.Y. Using biology to guide the treatment of sarcomas and aggressive connective-tissue tumours. Nat. Rev. Clin. Oncol. 2018, 15, 443-458. [CrossRef]

269. Cai, Y.; Mohseny, A.B.; Karperien, M.; Hogendoorn, P.C.; Zhou, G.; Cleton-Jansen, A.M. Inactive Wnt/ $\beta$-catenin pathway in conventional high-grade osteosarcoma. J. Pathol. 2010, 220, 24-33. [CrossRef]

270. Thomas, D.M. Wnts, bone and cancer. J. Pathol. 2010, 220,1-4. [CrossRef]

271. Matushansky, I.; Hernando, E.; Socci, N.D.; Mills, J.E.; Matos, T.A.; Edgar, M.A.; Singer, S.; Maki, R.G.; Cordon-Cardo, C. Derivation of sarcomas from mesenchymal stem cells via inactivation of the Wnt pathway. J. Clin. Investig. 2007, 117, 3248-3257. [CrossRef]

272. Hartmann, C. A Wnt canon orchestrating osteoblastogenesis. Trends Cell Biol. 2006, 16, 151-158. [CrossRef]

273. Krishnan, V.; Bryant, H.U.; Macdougald, O.A. Regulation of bone mass by Wnt signaling. J. Clin. Investig. 2006, 116, 1202-1209. [CrossRef]

274. Bodine, P.V.; Komm, B.S. Wnt signaling and osteoblastogenesis. Rev. Endocr. Metab. Disord. 2006, 7, 33-39. [CrossRef] [PubMed]

275. Ralston, S.H.; de Crombrugghe, B. Genetic regulation of bone mass and susceptibility to osteoporosis. Genes Dev. 2006, 20, 2492-2506. [CrossRef] [PubMed]

276. Baron, R.; Kneissel, M. WNT signaling in bone homeostasis and disease: From human mutations to treatments. Nat. Med. 2013, 19, 179-192. [CrossRef] [PubMed]

277. Patel, S.; Doble, B.W.; MacAulay, K.; Sinclair, E.M.; Drucker, D.J.; Woodgett, J.R. Tissue-specific role of glycogen synthase kinase $3 \beta$ in glucose homeostasis and insulin action. Mol. Cell Biol. 2008, 28, 6314-6328. [CrossRef] [PubMed]

278. Ragozzino, E.; Brancaccio, M.; Di Costanzo, A.; Scalabrì, F.; Andolfi, G.; Wanderlingh, L.G.; Patriarca, E.J.; Minchiotti, G.; Altamura, S.; Varrone, F.; et al. 6-Bromoindirubin-3'-oxime intercepts GSK3 signaling to promote and enhance skeletal muscle differentiation affecting miR-206 expression in mice. Sci. Rep. 2019, 9, 18091. [CrossRef] [PubMed]

279. Cao, H.; Chu, Y.; Lv, X.; Qiu, P.; Liu, C.; Zhang, H.; Li, D.; Peng, S.; Dou, Z.; Hua, J. GSK3 inhibitor-BIO regulates proliferation of immortalized pancreatic mesenchymal stem cells (iPMSCs). PLOS ONE 2012, 7, e31502. [CrossRef]

280. Tatullo, M.; Makeeva, I.; Rengo, S.; Rengo, C.; Spagnuolo, G.; Codispoti, B. Small molecule GSK-3 antagonists play a pivotal role in reducing the local inflammatory response, in promoting resident stem cell activation and in improving tissue repairing in regenerative dentistry. Histol. Histopathol. 2019, 34, 1195-1203. [CrossRef]

281. Sharma, P.; Allison, J.P. The future of immune checkpoint therapy. Science 2015, 348, 56-61. [CrossRef]

282. Atkins, M.B.; Larkin, J. Immunotherapy combined or sequenced with targeted therapy in the treatment of solid tumors: Current perspectives. J. Natl. Cancer Inst. 2016, 108, djv414. [CrossRef]

283. Cogdill, A.P.; Andrews, M.C.; Wargo, J.A. Hallmarks of response to immune checkpoint blockade. Br. J. Cancer 2017, 117, 1-7. [CrossRef]

284. Kim, J.M.; Chen, D.S. Immune escape to PD-L1/PD-1 blockade: Seven steps to success (or failure). Ann. Oncol. 2016, 27, 1492-1504. [CrossRef] [PubMed]

285. Jenkins, R.W.; Barbie, D.A.; Flaherty, K.T. Mechanisms of resistance to immune checkpoint inhibitors. Br. J. Cancer 2018, 118, 9-16. [CrossRef] [PubMed]

286. Postow, M.A.; Sidlow, R.; Hellmann, M.D. Immune-related adverse events associated with immune checkpoint blockade. N. Engl. J. Med. 2018, 378, 158-168. [CrossRef] [PubMed] 
287. Park, R.; Lopes, L.; Cristancho, C.R.; Riano, I.M.; Saeed, A. Treatment-related adverse events of combination immune checkpoint inhibitors: Systematic review and meta-analysis. Front. Oncol. 2020, 10, 258. [CrossRef] [PubMed]

288. Taylor, A.; Harker, J.A.; Chanthong, K.; Stevenson, P.G.; Zuniga, E.I.; Rudd, C.E. Glycogen synthase kinase 3 inactivation drives T-bet-mediated downregulation of co-receptor PD-1 to enhance CD8 ${ }^{+}$cytolytic T cell responses. Immunity 2016, 44, 274-286. [CrossRef]

289. Taylor, A.; Rothstein, D.; Rudd, C.E. Small-molecule inhibition of PD-1 transcription is an effective alternative to antibody blockade in cancer therapy. Cancer Res. 2018, 78, 706-717. [CrossRef]

290. Jiao, S.; Xia, W.; Yamaguchi, H.; Wei, Y.; Chen, M.K.; Hsu, J.M.; Hsu, J.L.; Yu, W.H.; Du, Y.; Lee, H.H.; et al. PARP inhibitor upregulates PD-L1 expression and enhances cancer-associated immunosuppression. Clin. Cancer Res. 2017, 23, 3711-3720. [CrossRef]

291. Taylor, A.; Rudd, C.E. Glycogen synthase kinase 3 inactivation compensates for the lack of CD28 in the priming of $\mathrm{CD}^{+}$cytotoxic T-cells: Implications for anti-PD-1 immunotherapy. Front. Immunol. 2017, 8, 1653. [CrossRef]

292. Kamphorst, A.O.; Wieland, A.; Nasti, T.; Yang, S.; Zhang, R.; Barber, D.L.; Konieczny, B.T.; Daugherty, C.Z.; Koenig, L.; Yu, K.; et al. Rescue of exhausted CD8 T cells by PD-1-targeted therapies is CD28-dependent. Science 2017, 355, 1423-1427. [CrossRef]

293. Taylor, A.; Rudd, C.E. Small molecule inhibition of glycogen synthase kinase-3 in cancer immunotherapy. Adv. Exp. Med. Biol. 2019, 1164, 225-233. [CrossRef]

294. De Simone, V.; Pallone, F.; Monteleone, G.; Stolfi, C. Role of $\mathrm{T}_{\mathrm{H}} 17$ cytokines in the control of colorectal cancer. Oncoimmunology 2013, 2, e26617. [CrossRef] [PubMed]

295. Wu, D.; Wu, P.; Huang, Q.; Liu, Y.; Ye, J.; Huang, J. Interleukin-17: A promoter in colorectal cancer progression. Clin. Dev. Immunol. 2013, 2013, 436307. [CrossRef]

296. Housseau, F.; Wu, S.; Wick, E.C.; Fan, H.; Wu, X.; Llosa, N.J.; Smith, K.N.; Tam, A.; Ganguly, S.; Wanyiri, J.W.; et al. Redundant innate and adaptive sources of IL17 production drive colon tumorigenesis. Cancer Res. 2016, 76, 2115-2124. [CrossRef] [PubMed]

297. Amicarella, F.; Muraro, M.G.; Hirt, C.; Cremonesi, E.; Padovan, E.; Mele, V.; Governa, V.; Han, J.; Huber, X.; Droeser, R.A.; et al. Dual role of tumour-infiltrating T helper 17 cells in human colorectal cancer. Gut 2017, 66, 692-704. [CrossRef] [PubMed]

298. He, S.; Fei, M.; Wu, Y.; Zheng, D.; Wan, D.; Wang, L.; Li, D. Distribution and clinical significance of Th17 cells in the tumor microenvironment and peripheral blood of pancreatic cancer patients. Int. J. Mol. Sci. 2011, 12, 7424-7437. [CrossRef] [PubMed]

299. Wang, L.; Yi, T.; Kortylewski, M.; Pardoll, D.M.; Zeng, D.; Yu, H. IL-17 can promote tumor growth through an IL-6-Stat3 signaling pathway. J. Exp. Med. 2009, 206, 1457-1464. [CrossRef] [PubMed]

300. De Simone, V.; Franzè, E.; Ronchetti, G.; Colantoni, A.; Fantini, M.C.; Di Fusco, D.; Sica, G.S.; Sileri, P.; MacDonald, T.T.; Pallone, F.; et al. Th17-type cytokines, IL-6 and TNF- $\alpha$ synergistically activate STAT3 and NF-kB to promote colorectal cancer cell growth. Oncogene 2015, 34, 3493-3503. [CrossRef]

301. Loncle, C.; Bonjoch, L.; Folch-Puy, E.; Lopez-Millan, M.B.; Lac, S.; Molejon, M.I.; Chuluyan, E.; Cordelier, P.; Dubus, P.; Lomberk, G.; et al. IL17 functions through the novel REG3 $\beta$-JAK2-STAT3 inflammatory pathway to promote the transition from chronic pancreatitis to pancreatic cancer. Cancer Res. 2015, 75, 4852-4862. [CrossRef]

302. Beurel, E.; Jope, R.S. Differential regulation of STAT family members by glycogen synthase kinase-3. J. Biol. Chem. 2008, 283, 21934-21944. [CrossRef]

303. Beurel, E.; Yeh, W.I.; Michalek, S.M.; Harrington, L.E.; Jope, R.S. Glycogen synthase kinase-3 is an early determinant in the differentiation of pathogenic Th17 cells. J. Immunol. 2011, 186, 1391-1398. [CrossRef]

304. Prior, I.A.; Lewis, P.D.; Mattos, C. A comprehensive survey of Ras mutations in cancer. Cancer Res. 2012, 72, 2457-2467. [CrossRef] [PubMed]

305. Jinesh, G.G.; Sambandam, V.; Vijayaraghavan, S.; Balaji, K.; Mukherjee, S. Molecular genetics and cellular events of K-Ras-driven tumorigenesis. Oncogene 2018, 37, 839-846. [CrossRef] [PubMed]

306. Cox, A.D.; Fesik, S.W.; Kimmelman, A.C.; Luo, J.; Der, C.J. Drugging the undruggable RAS: Mission possible? Nat. Rev. Drug Discov. 2014, 13, 828-851. [CrossRef] [PubMed]

307. Ostrem, J.M.; Shokat, K.M. Direct small-molecule inhibitors of KRAS: From structural insights to mechanism-based design. Nat. Rev. Drug Discov. 2016, 15, 771-785. [CrossRef] [PubMed] 
308. Patricelli, M.P.; Janes, M.R.; Li, L.S.; Hansen, R.; Peters, U.; Kessler, L.V.; Chen, Y.; Kucharski, J.M.; Feng, J.; Ely, T.; et al. Selective inhibition of oncogenic KRAS output with small molecules targeting the inactive state. Cancer Discov. 2016, 6, 316-329. [CrossRef] [PubMed]

309. Welsch, M.E.; Kaplan, A.; Chambers, J.M.; Stokes, M.E.; Bos, P.H.; Zask, A.; Zhang, Y.; Sanchez-Martin, M.; Badgley, M.A.; Huang, C.S.; et al. Multivalent small-molecule pan-RAS inhibitors. Cell 2017, 168, 878-889. [CrossRef] [PubMed]

310. Keeton, A.B.; Salter, E.A.; Piazza, G.A. The RAS-effector interaction as a drug target. Cancer Res. 2017, 77, 221-226. [CrossRef]

311. Canon, J.; Rex, K.; Saiki, A.Y.; Mohr, C.; Cooke, K.; Bagal, D.; Gaida, K.; Holt, T.; Knutson, C.G.; Koppada, N.; et al. The clinical KRAS(G12C) inhibitor AMG 510 drives anti-tumour immunity. Nature 2019, 575, 217-223. [CrossRef]

312. Hallin, J.; Engstrom, L.D.; Hargis, L.; Calinisan, A.; Aranda, R.; Briere, D.M.; Sudhakar, N.; Bowcut, V.; Baer, B.R.; Ballard, J.A.; et al. The KRAS ${ }^{\mathrm{G} 12 \mathrm{C}}$ inhibitor MRTX849 provides insight toward therapeutic susceptibility of KRAS-mutant cancers in mouse models and patients. Cancer Discov. 2020, 10, 54-71. [CrossRef]

313. Babina, I.S.; Turner, N.C. Advances and challenges in targeting FGFR signalling in cancer. Nat. Rev. Cancer 2017, 17, 318-332. [CrossRef]

314. Harrison, P.T.; Huang, P.H. Exploiting vulnerabilities in cancer signalling networks to combat targeted therapy resistance. Essays Biochem. 2018, 62, 583-593. [CrossRef] [PubMed]

315. Xue, J.Y.; Zhao, Y.; Aronowitz, J.; Mai, T.T.; Vides, A.; Qeriqi, B.; Kim, D.; Li, C.; de Stanchina, E.; Mazutis, L.; et al. Rapid non-uniform adaptation to conformation-specific KRAS(G12C) inhibition. Nature 2020, 577, 421-425. [CrossRef] [PubMed]

316. Hata, A.N.; Shaw, A.T. Resistance looms for KRAS ${ }^{\mathrm{G} 12 \mathrm{C}}$ inhibitors. Nat. Med. 2020, 26, 169-170. [CrossRef] [PubMed]

317. Ryan, M.B.; Fece de la Cruz, F.; Phat, S.; Myers, D.T.; Wong, E.; Shahzade, H.A.; Hong, C.B.; Corcoran, R.B. Vertical pathway inhibition overcomes adaptive feedback resistance to KRAS ${ }^{\mathrm{G} 12 \mathrm{C}}$ inhibition. Clin. Cancer Res. 2020, 26, 1633-1643. [CrossRef] [PubMed]

318. Yaeger, R.; Solit, D.B. Overcoming adaptive resistance to KRAS inhibitors through vertical pathway targeting. Clin. Cancer Res. 2020, 26, 1538-1540. [CrossRef] [PubMed]

319. June, C.H. Drugging the undruggable ras-immunotherapy to the rescue? N. Engl. J. Med. 2016, 375, 2286-2289. [CrossRef]

320. Chatani, P.D.; Yang, J.C. Mutated RAS: Targeting the "untargetable" with T cells. Clin. Cancer Res. 2020, 26, 537-544. [CrossRef]

(C) 2020 by the authors. Licensee MDPI, Basel, Switzerland. This article is an open access article distributed under the terms and conditions of the Creative Commons Attribution (CC BY) license (http://creativecommons.org/licenses/by/4.0/). 